\title{
Salt Budget for West Pond, Utah, April 1987 to April 1988
}

By Kidd M. Waddell ${ }^{1}$, J. Wallace Gwynn ${ }^{2}$, Carole Burden ${ }^{1}$, and Steven R. Wold ${ }^{1}$

U.S. GEOLOGICAL SURVEY

Water-Resources Investigations Report 91-4117

Prepared in cooperation with the

UTAH GEOLOGICAL SURVEY AND THE

UTAH DEPARTMENT OF NATURAL RESOURCES,

DIVISION OF WATER RESOURCES

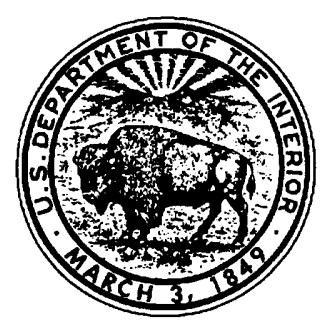

Salt Lake City, Utah

1992

\footnotetext{
1 U.S. Geological Survey

${ }^{2}$ Utah Geological Survey
} 
U.S. DEPARTMENT OF THE INIERIOR

MANUEI LUJAN, JR., Secretary

U.S. GEOLOGICAL SURVEY

Dallas L. Peck, Director

For additional information write to:

District Chief U.S. Geological Survey, WRD Room 1016 Administration Building 1745 West 1700 South

Salt Lake City, Utah 84104
Copies of this report can be purchased from:

U.S. Geological Survey

Books and Open-File Reports Section Federal Center

Box 25425

Denver, Colorado 80225 


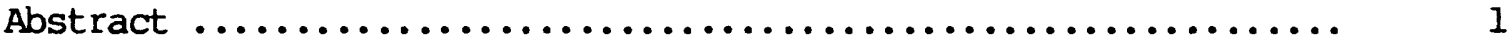

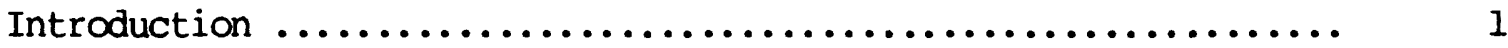

Purpose and scope $\ldots \ldots \ldots \ldots \ldots \ldots \ldots \ldots \ldots \ldots \ldots \ldots \ldots \ldots, \ldots \ldots, 2$

Well- and spring-numbering system $\ldots \ldots \ldots \ldots \ldots \ldots \ldots \ldots \ldots, \quad 4$

Data collection and analysis $\ldots \ldots \ldots \ldots \ldots \ldots \ldots \ldots \ldots \ldots \ldots \ldots \ldots \ldots \ldots \ldots \ldots, 4$

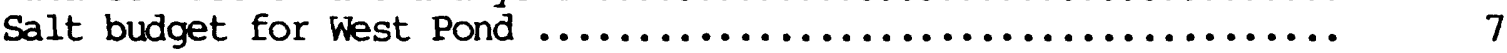

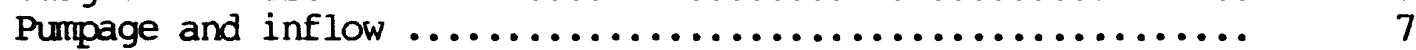

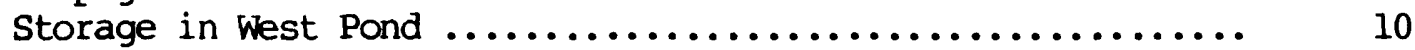

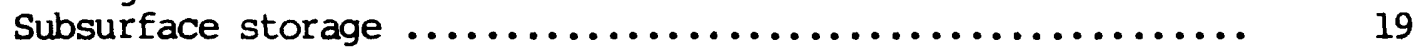

Withdrawals by American Magnesium Corporation (AMAX) $\ldots \ldots \ldots . .20$

Outflow through Newfoundland weir ........................ 20

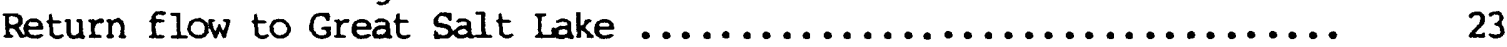

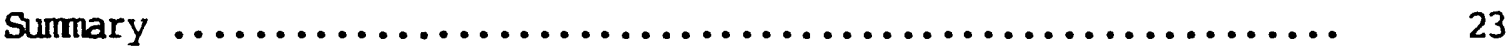

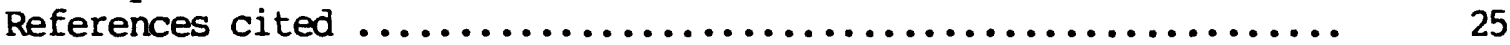

\section{ILLUSTRATIONS}

Figure 1. Map showing location of study area and data-collection

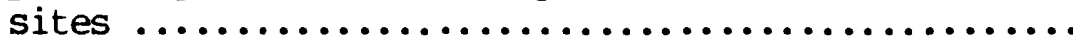

2. Diagram showing well- and spring-numbering system

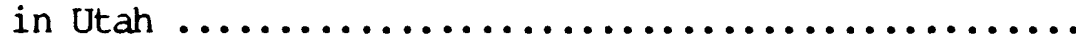

3. Graphs showing volumes, concentration of dissolved solids, and salt loads of brine pumped from Great Salt Lake into West Pond, April 1987 to

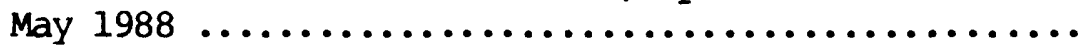

4. Map showing West Pond sampling sites and section divisions used for computing salt loads,

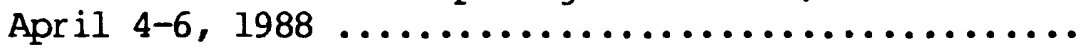

5. Graph showing relation of density and concentration of dissolved solids in brine for hest Pond ..........

6. Graphs showing elevation-volume relation for sections

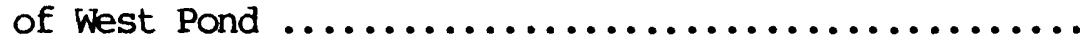

7. Map showing West Pond sections used for computing salt loads, December 10, $1987 \ldots \ldots \ldots \ldots \ldots \ldots \ldots \ldots$

8. Graphs showing volumes, concentration of dissolved solids, and salt loads of brine pumped from west Pond into American Magnesium Corporation solar ponds, January to May 1988 ..........................

9. Graphs showing volumes, concentration of dissolved solids, and salt loads of brine for outflow from West Pond through Newfoundland weir, November 1987 to May $1988 \ldots \ldots \ldots \ldots \ldots \ldots \ldots \ldots \ldots \ldots \ldots \ldots \ldots . . . \ldots \ldots$

10. Photograph showing view of West Pond and return flow to Great Salt Lake, December 18, 1987 
Page

1. Responsible agencies, performing agencies and companies, and data-collection schedule for West Pond monitoring program, 1987-88 .............

2. Salt budget for West Pond, April 10, 1987, to April 6, 1988 ............................

3. Chemical analyses and field measurements of temperature and specific gravity for West Pond, April 4-6, 1988

4. Summary of volume of brine and tons of salt for sections of West Pond, April 4-6, 1988

5. Sumary of volume of brine and tons of salt for sections of West Pond, December 10, 1987

6. Compilation of volumes and salt loads for sections of West Pond, April 4-6, 1988 
CONVERSION FACTORS, VERTICAL DATUM,

AND ABBREVIATED WATER-QUALITY UNITS

\section{Multiply}

acre

acre-foot

cubic foot per second

foot

inch

mile

ton (short)
By

$$
\begin{gathered}
\quad 0.4047 \\
4,047 \\
0.001233 \\
1,233 \\
0.02832 \\
0.3048 \\
2.54 \\
1.609 \\
0.9072
\end{gathered}
$$

To obtain

square hectometer square meter cubic hectometer cubic meter cubic meter per second meter centimeter kilometer metric ton or megagram

Water temperature is given in degrees Celsius $\left({ }^{\circ} \mathrm{C}\right)$, which can be converted to degrees Fahrenheit $\left({ }^{\circ} \mathrm{F}\right)$ by the following equation:

$$
{ }^{\circ} \mathrm{F}=1.8\left({ }^{\circ} \mathrm{C}\right)+.32 \text {. }
$$

Sea level: In this report "sea level" refers to the National Geodetic Vertical Datum of 1929--a geodetic datum derived fram a general adjustment of the first-order level nets of the United States and Canada, formerly called Sea Level Datum of 1929.

Chemical concentration and water temperature are given only in metric units. Chemical concentration is given in grams per milliliter or milligrams per liter. Grams and milligrams per liter are units expressing the solute per unit volume (liter) of water. 
SALT BUDGET FOR WEST POND, UTAH,

APRIL 1987 TO APRIL 1988

By Kidd M. Waddell ${ }^{1}$, J. Wallace Gwynn ${ }^{2}$, Carole B. Burden ${ }^{1}$, and Steven R. Wold ${ }^{1}$

\section{ARSTRACT}

During the first year of the West Desert pumping project (April 10, 1987, to April 6, 1988), data were collected as part of a monitoring program to determine the quantity and distribution or fate of dissolved salts that were pumped into West Pond, Utah. These data were used to prepare a salt budget that indicates about 317 to 351 million tons of salt, or about 6.5 to 7.2 percent of the salt contained in Great Salt Lake, was pumped from the lake into West Pond. Only about 28 to 34 million tons, or 8 to 10 percent of the salt pumped, was returned to the lake.

Of the quantity of salt pumped into West Pond, 12.2 to $13.4 \mathrm{million}$ tons, or 3.6 to 4 percent, was withdrawn by American Magnesium Corporation; 4.5 to $9.9 \mathrm{million}$ tons, or 1.3 to 3 percent, infiltrated areas inundated by the storage in West Pond; 189 to 240 million tons, or 56 to 72 percent, was stored in West Pond; and about 36.5 to 44.5 million tons, or 11 to 13 percent, discharged from West Pond through the Newfoundland weir. About 17 percent of the salt pumped from the lake could not be accounted for by the monitoring program.

\section{INIRODUCTION}

In 1983, the level of Great Salt Lake began a rapid rise, and by 1986 , the level had reached a new historic high of 4,211.85 feet above sea level, causing flooding around the lake. To combat the rising waters, the State implemented two lake-level-control measures: (1) Breaching the Southern Pacific Transportation Co. causeway, and (2) beginning the West Desert pumping project.

In 1984, the Southern Pacific Transportation Co. causeway was breached by a 270-foot opening at a site near Lakeside on the western edge of the lake. The breach was designed to equalize the hydraulic-head differential that had developed between the parts of the lake to the south and north of the causeway, the water to the south being the highest. Although the project was successful in lowering the level of the south part by about 9 inches, the level of the entire lake continued to $r$ ise in response to above-average precipitation over the entire basin.

U.S. Geological Survey

2 Utah Geological Survey 
The West Desert pumping project was the second lake-level-control measure implemented. The pumping project was designed to remove water from Great salt Lake and store it in Newfoundland Evaporation Basin, locally known as West Pond, where additional storage area was available, and where additional surface area would provide for a net increase in evaporation. The local name, West Pond, is used throughout this report. On April 10, 1987, the first of three purms was started at the new pumping station at Hogup Ridge (fig. 1) on the western shore of Great Salt Lake. The brine was lifted from the north part of the lake and discharged westward through a 4-mile long canal. At the end of the canal, the brine spread out on the floor of the Great Salt Lake Desert north of the Southern Pacific Transportation Co. causeway, and then flowed southward through a trestle into West Pond.

West Pond occupies a natural basin depression in the Great Salt Lake Desert. The two Bonneville Dike segments (south of Floating Island) (fig. 1) were built to protect the Bonneville Salt Flats to the west and the interstate freeway to the south. The Newfoundland Dike (south of the Newfoundland Mountains) (fig. 1) was built to keep the water from flowing to the nor theast and into the lake. The Newfoundland Dike also was designed to provide control of the elevation of the water through a series of adjustable weirs. When filled to its capacity elevation of 4,216.5 feet above sea level, the maximum depth of West Pond is about 7 feet, and it covers an area of about 320,000 acres.

The quantity of inflow and outflow of brine for West Pond is controlled by the rate of pumpage into the pond, by evaporation, by withdrawal of brine by American Magnesium Corporation (AMAX), and by the elevation of the weirs at the Newfoundland Dike. AMAX constructed a solar ponding complex at the southern end of West Pond in which brine from West Pond is stored and used as feedstock for their new brine-concentration facility.

During the first year of the West Desert pumping project (April 10, 1987, to April 6, 1988), data were collected as part of a monitoring program to determine the quantity and distribution or fate of dissolved salts that were pumped into West Pond, Utah. The study was done by the U.S. Geological Survey in cooperation with the Utah Geological Survey and the Utah Department of Natural Resources, Division of Water Resources.

\section{Purpose and Scope}

The purpose of this report is to present the results of a study conducted by the U.S. Geological Survey to evaluate the quantity and distribution of dissolved salts that were pumped into West Pond from Great Salt Lake and determine the quantity of outflow from West Pond to Great Salt Lake. A salt budget was prepared to make the evaluations of salt distribution.

Data used for the evaluation, such as specific gravity, water levels, and chemical constituents of brine, were collected as part of a monitoring program that began April 10, 1987, when pumping to West Pond was started. Pumping records and concentration of brine at the pumping station and at the AMAX facility, and outflow and concentration at the Newfoundland weir were used to estimate the inflow and outflow of brine to and from West Pond. These data were used to prepare a salt budget for West Pond. 


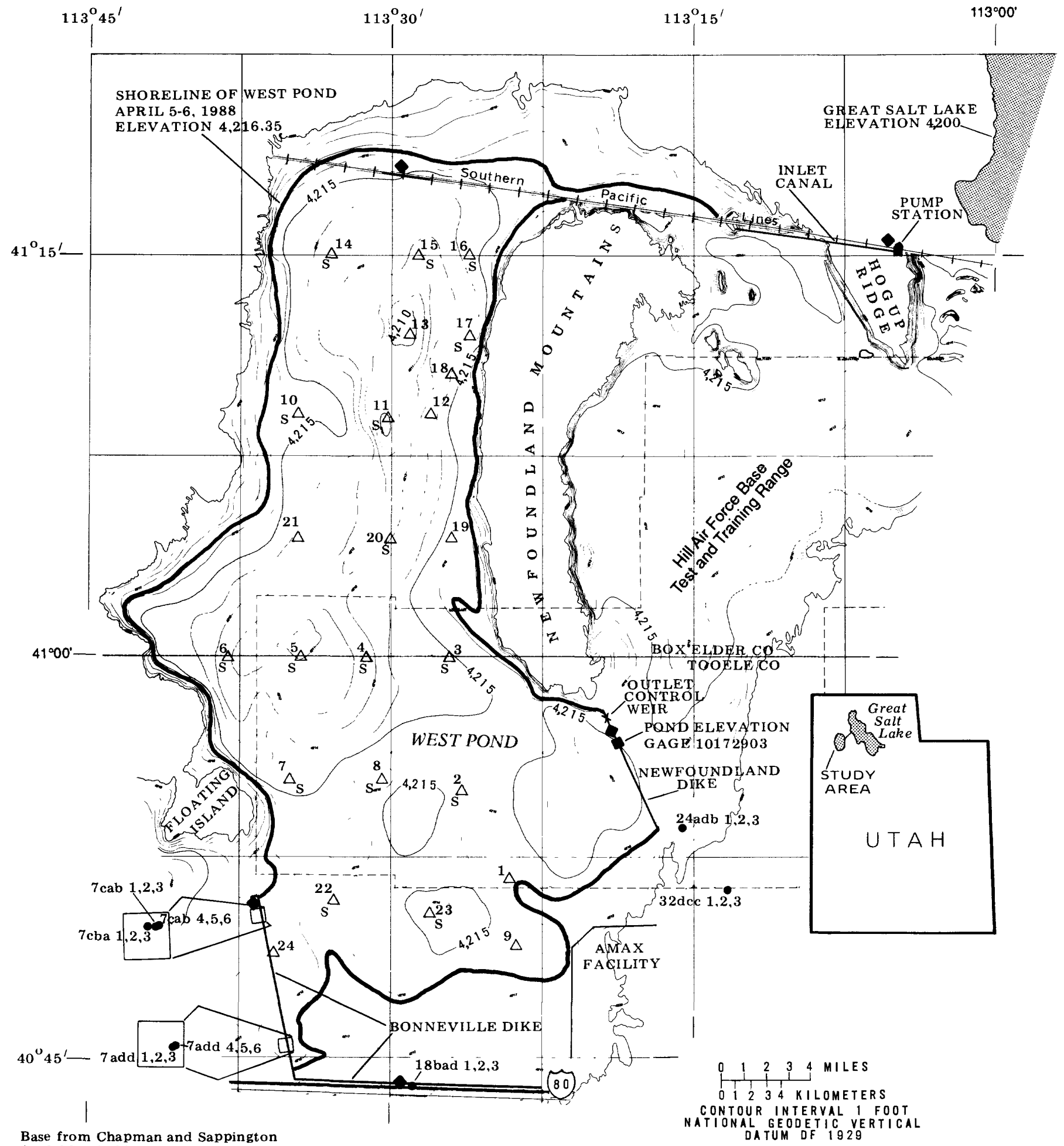

Base from Chapman and Sappington $1: 96,000,1986$

EXPLANATION

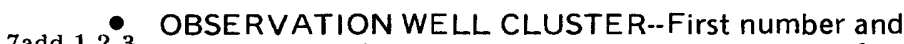
letters are reference to location. Last number refers to each of 3 wells in cluster: One shallow, one intermediate, and one deep well in each cluster. Field measurement of water levels, specific gravity, and temperature in table 1 , and samples collected for complete chemical analysis in table 2
${ }^{20} \triangle$ SITE IN WEST POND WHERE MEASUREMENTS WERE MADE FOR WATER TEMPERATURE AND SPECIFIC GRAVITY (TABLE 3)--Number is sampling site. S indicates sample collected for complete chemical analysis

SITE AT WHICH CLIMATIC DATA WERE COLLECTED

Figure 1.--Location of study area and data-collection sites. 
Data shown in the salt budget include the quantity of pumpage and inflow to West Pond from Great Salt Lake, the quantity of storage in West Pond, the quantity of salt stored in subsurface sediments, withdrawals by AMAX, and outflow through the Newfoundland weir that returns to Great Salt Lake or remains as a shallow lake in an area east of the Newfoundland Mountains.

\section{Well- and Spring-Numbering System}

The system of numbering wells and springs in Utah is based on the cadastral land-survey system of the U.S. Government. The number, in addition to designating the well, describes its position in the land net. By the landsurvey system, the State is divided into four quadrants by the Salt Lake Base Line and the Salt Lake Meridian, and these quadrants are designated by the uppercase letters A, B, C, and D, indicating the northeast, northwest, southwest, and southeast quadrants, respectively. Numbers designating the township and range (in that order) follow the quadrant letter, and all three are enclosed in parentheses. The number after the parentheses indicates the section, and it is followed by three letters indicating the quarter section, the quarter-quarter section, and the quarter-quarter-quarter section-generally 10 acres $^{1}$; the letters $\mathrm{a}, \mathrm{b}, \mathrm{c}$, and $\mathrm{d}$ indicate, respectively, the northeast, northwest, southwest, and southeast quarters of each subdivision. The number after the letters is the serial number of the well within the 10acre tract. If a well cannot be located within a 10-acre tract, one or two location letters are used and the serial number is omitted. Thus, (B-115) $7 \mathrm{cab}-3$ designates the third well constructed or visited in the $\mathrm{NW}^{\frac{1}{4}} \mathrm{NE}_{\frac{1}{4}} \mathrm{SW}^{\frac{1}{4}}$ sec. $7, \mathrm{~T} .1 \mathrm{~N} ., \mathrm{R} .15 \mathrm{~W}$. The numbering system is illustrated in figure 2 .

\section{DATA COLLECTION AND ANALYSIS}

To evaluate the quantity and distribution or fate of dissolved salts that were pumped into West Pond, the following were monitored: (1) The quantity of brine pumped from Great Salt Lake into West Pond, (2) the quantity of brine pumped from West Pond by AMAX, (3) the quantity of brine stored in West Pond, (4) the quantity of outflow from West Pond, and (5) the salinity of the brines.

The agencies and companies collecting data necessary for the monitoring program were Eckhoff, Watson, and Preator Engineering (EWP); Utah Geological Survey (UGS); U.S. Geological Survey (USGS); Utah State University (USU); and American Magnesium Corporation (AMAX). The responsible agencies, performing agencies and companies, and period and frequency of data collection are listed in table 1.

1 Although the basic land unit, the section, is theoretically 1 square mile, many sections are irregular. Such sections are subdivided into 10-acre tracts, generally beginning at the southeast corner, and the surplus or shortage is taken up in the tracts along the north and west sides of the section. 


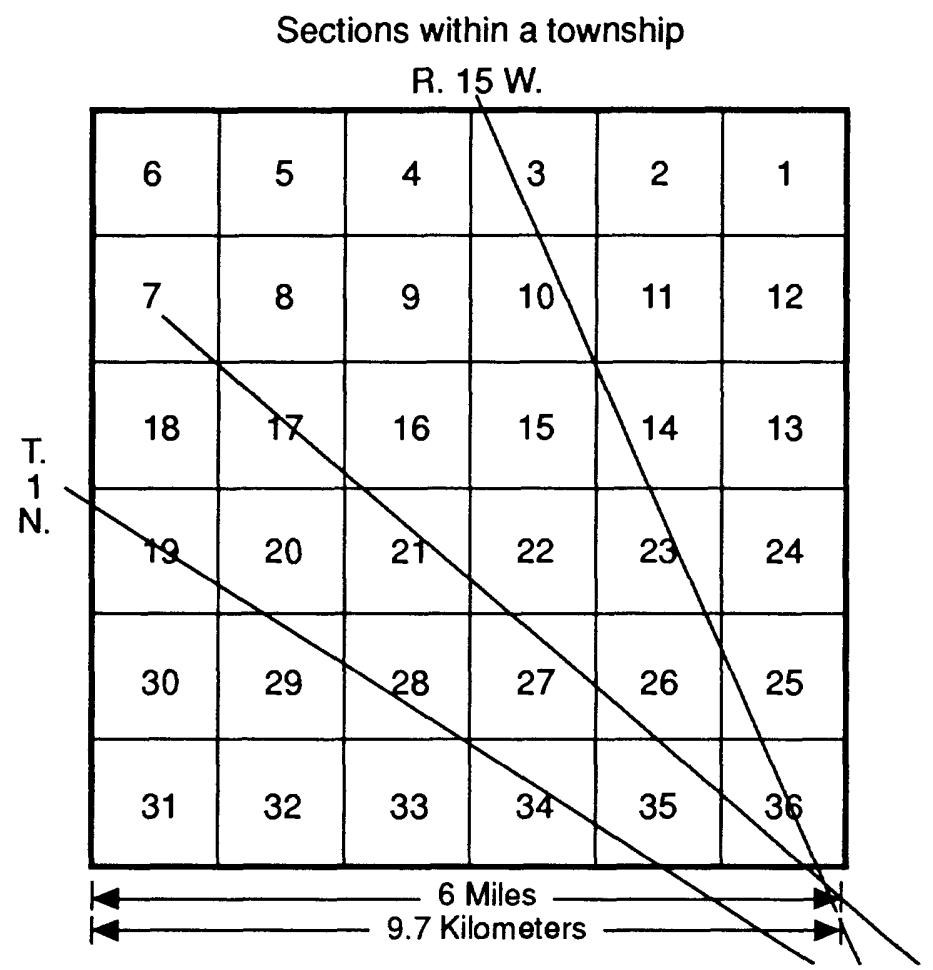

Tracts within a section

Section 7
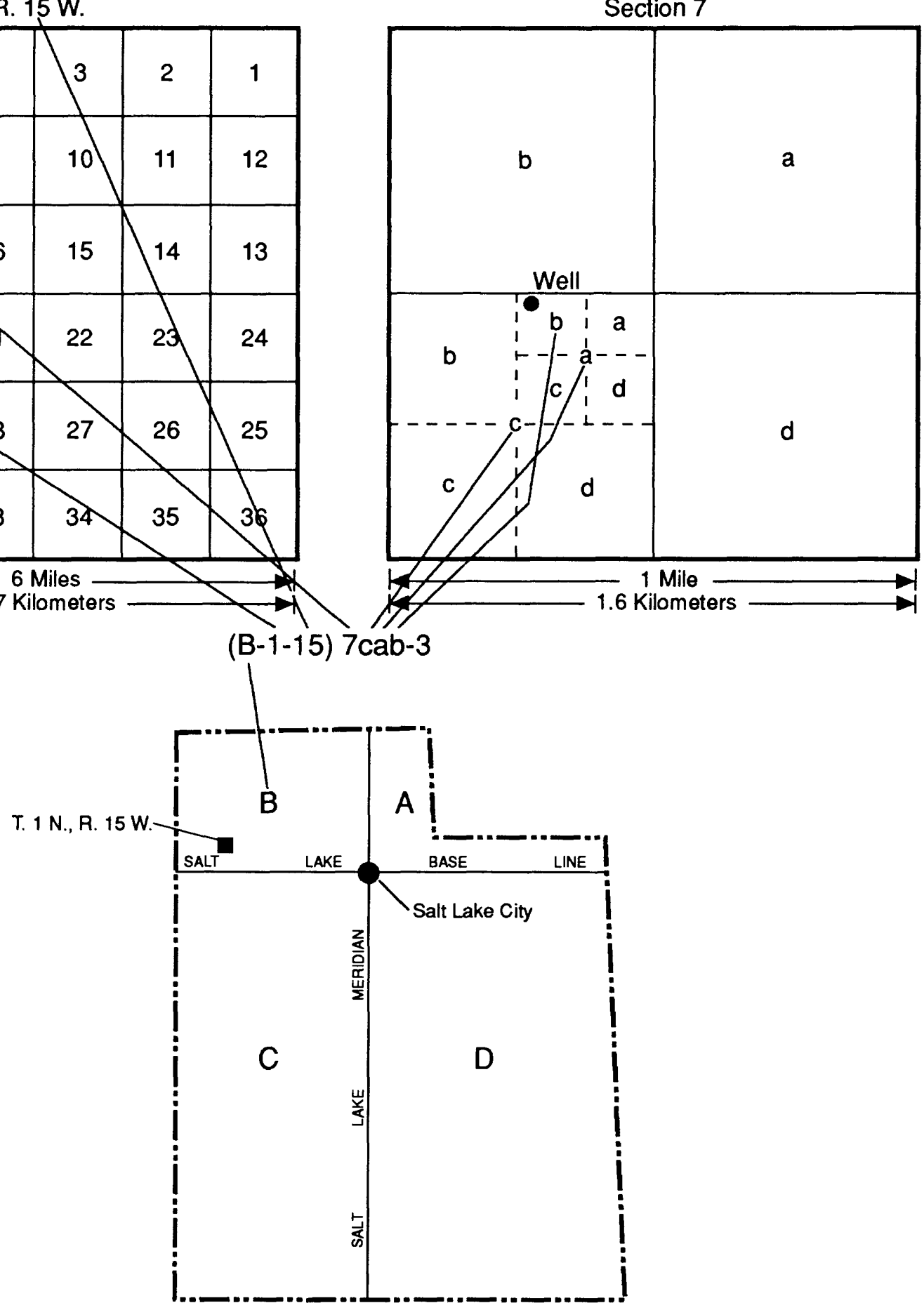

Figure 2.--Well- and spring-numbering system in Utah. 
Table 1.--Responsible agencies, performing agencies and companies, and data-collection schedule

for West Pond monitoring program, 1987-88

Responsible agency: DWR, Division of Water Resources; UGS, Utah Geological Survey.

Performing agency or company: EWP, Eckhoff, Watson, and Preator Engineering; UGS, Utah Geological Survey; USGS, U.S. Geological Survey; USU, Utah State University; AMAX, American Magnesium Corp.

\begin{tabular}{|c|c|c|c|c|}
\hline \multicolumn{2}{|c|}{$\begin{array}{l}\text { Responsible } \\
\text { agency }\end{array}$} & \multirow{2}{*}{$\begin{array}{l}\text { Performing } \\
\text { agency } \\
\text { or company }\end{array}$} & \multirow[t]{2}{*}{$\begin{array}{l}\text { Beginning } \\
\text { date of } \\
\text { collection }\end{array}$} & \multirow[t]{2}{*}{$\begin{array}{l}\text { Frequency of } \\
\text { collection }\end{array}$} \\
\hline Pumpage to West Pond & & & & \\
\hline $\begin{array}{l}\text { Quantity } \\
\text { Quality }\end{array}$ & DWR & EWP & $04-10-87$ & hourly \\
\hline Specific gravity & DWR & EWP/UGS & $04-10-87$ & weekly \\
\hline Major ions & DWR & USGS & $04-10-87$ & monthly \\
\hline \multicolumn{5}{|l|}{ Outflow } \\
\hline Quantity & DWR & EWP & $04-10-87$ & hourly \\
\hline Quality & UGS & USGS & $01-07-88$ & monthì \\
\hline \multirow[t]{2}{*}{ Pond elevation } & DWR & USU & $06-01-87$ & inf requent \\
\hline & DWR & USGS & $12-01-87$ & continuous \\
\hline Precipitation & DWR & USU & $04-10-87$ & continuous \\
\hline Evaporation & DWR & USU & $04-10-87$ & continuous \\
\hline West Pond quality & UGS & UGS/USGS & $04-06-88$ & annual \\
\hline Amax diversions & DWR & AMAX & $01-10-88$ & continuous \\
\hline Ground water & DWR & USGS & & \\
\hline Levels & & & $06-01-87$ & monthly \\
\hline \multicolumn{5}{|l|}{ Quality } \\
\hline \multirow{2}{*}{\multicolumn{3}{|c|}{$\begin{array}{l}\text { Specific gravity } \\
\text { Major ions }\end{array}$}} & $06-01-87$ & monthly \\
\hline & & & $07-01-87$ & quarterly \\
\hline
\end{tabular}

Pumpage to West Pond was computed by EWP using rating curves for the pumps in conjunction with total hours of pumping and fuel consumption. The rating curves provide the discharge as a function of the revolutions per minute of the purp. AMAX used a similar method to compute discharge from pumps that divert brine from West Pond to their evaporation ponds.

Outflow from west Pond was computed using weir ratings and pond-elevation data. The weir ratings provide the discharge as a function of the difference between the static lake elevation and the elevation of the weir. Pondelevation data were recorded continuously at a gage on the Newfoundland Dike (fig. 1). 
Precipitation and evaporation were computed from data collected at five climatic-data sites on and near West Pond (fig. 1). Climatic data included wind speed and direction, solar radiation, relative humidity, and average daily temperature.

\section{SALT BUDGET FOR WEST POND}

The quantity of salt pumped into West Pond from Great Salt Lake during April 10, 1987, to April 6, 1988, should approximate the quantity of salt stored in the pond on April 6, 1988, plus that which left the pond through the Newfoundland weir, was withdrawn by AMAX, or entered into the shallow groundwater storage in West Pond. An accounting of the tonnages, considering the effect of possible errors, is shown in table 2 .

Considering mean values of tonnages in table 2, 64 percent of the quantity of salt pumped from Great Salt Lake was stored in West Pond on April 6, 1988. The remaining quantity, 36 percent, comprised withdrawal by AMAX, subsurface infiltration into areas inundated by storage in West Pond, and discharge from West Pond through the Newfoundland weir.

The estimate based on mean values in table 2 indicates that about 58 million tons or 17 percent of the salt that was pumped into West Pond is not accounted for by the budget calculations. Computations based on the minimum estimated inflow, maximum estimated outflow, and maximum estimated storage indicate that about $8.8 \mathrm{million}$ tons or about 3 percent of the pumped salt is unaccounted for. Most of the inaccuracy in the budget is believed to be associated with the elevation-volume relations which affect the computed loads of salt stored in West Pond and with estimates of outflow through the Newfoundland weir. (See section "Storage in West Pond".)

\section{Pumpage and Inflow}

Brine inflow to West Pond consists of water pumped from Great Salt Lake by three large pumps whose combined maximum pumping capacity is approximately 3,300 cubic feet per second. The design pumping rate is 2,800 cubic feet per second. The monthly and cumulative volumes and salt loads of brine pumped to West Pond are shown in figure 3. These data were obtained from monthly reports prepared by EWP.

Because of the annual rise and fall of the Great Salt Lake level, the brine concentration varies throughout the year. Thus, for a given pumping rate, the quantity of salt that is pumped during a given month is dependent on the brine salinity. The concentration of dissolved solids of the brine that was pumped from April 1987 to May 1988 is shown in figure 3.

The load of dissolved salts entering West Pond each month was computed from the product of the monthly volume in acre-feet and the average concentration of dissolved solids for a given month in tons per acre-foot (the factor for converting the concentration of dissolved solids in grams per liter to tons per acre-foot is 1.3564). The graph showing cumulative salt loads in figure 3 indicates that approximately $334 \mathrm{million}$ tons of salt was pumped fram the lake during April 10, 1987, to April 6, 1988. 
Table 2. - Salt budget for West Pond, April 10, 1987, to April 6, 1988

Estimate of salt load, in millions of tons

Minimum Mean Maximum

Pumpage and inflow

fram Great Salt Lake ${ }^{l}$

317

334

351

Storage in West Pond ${ }^{2}$

189

215

240

Subsurface infiltration ${ }^{3}$

4.5

7.2

9.9

AMAX withdrawal ${ }^{l}$

12.2

12.8

13.4

Newfoundland wei $r^{4}$

36.5

40.6

44.7

Unacoounted salt

(As percentage of inflow)

58

(17 percent)

1 Minimum and maximum values were computed assuming \pm 5 percent error in measurements of pumping.

2 The maximum value was camputed with elevation-volume curves prepared by EWP and the minimum value was computed with U.S. Geological Survey elevationvolume curves.

3 Minimum and maximum values were based on an estimated range of thicknesses for the unsaturated zone, at West Pond and east of the Newfoundland Mountains.

4 Minimum and maximum values were computed using +10 percent error (Brent S. Bingham, Bingham Engineering, oral commun., August 9, 1990). 

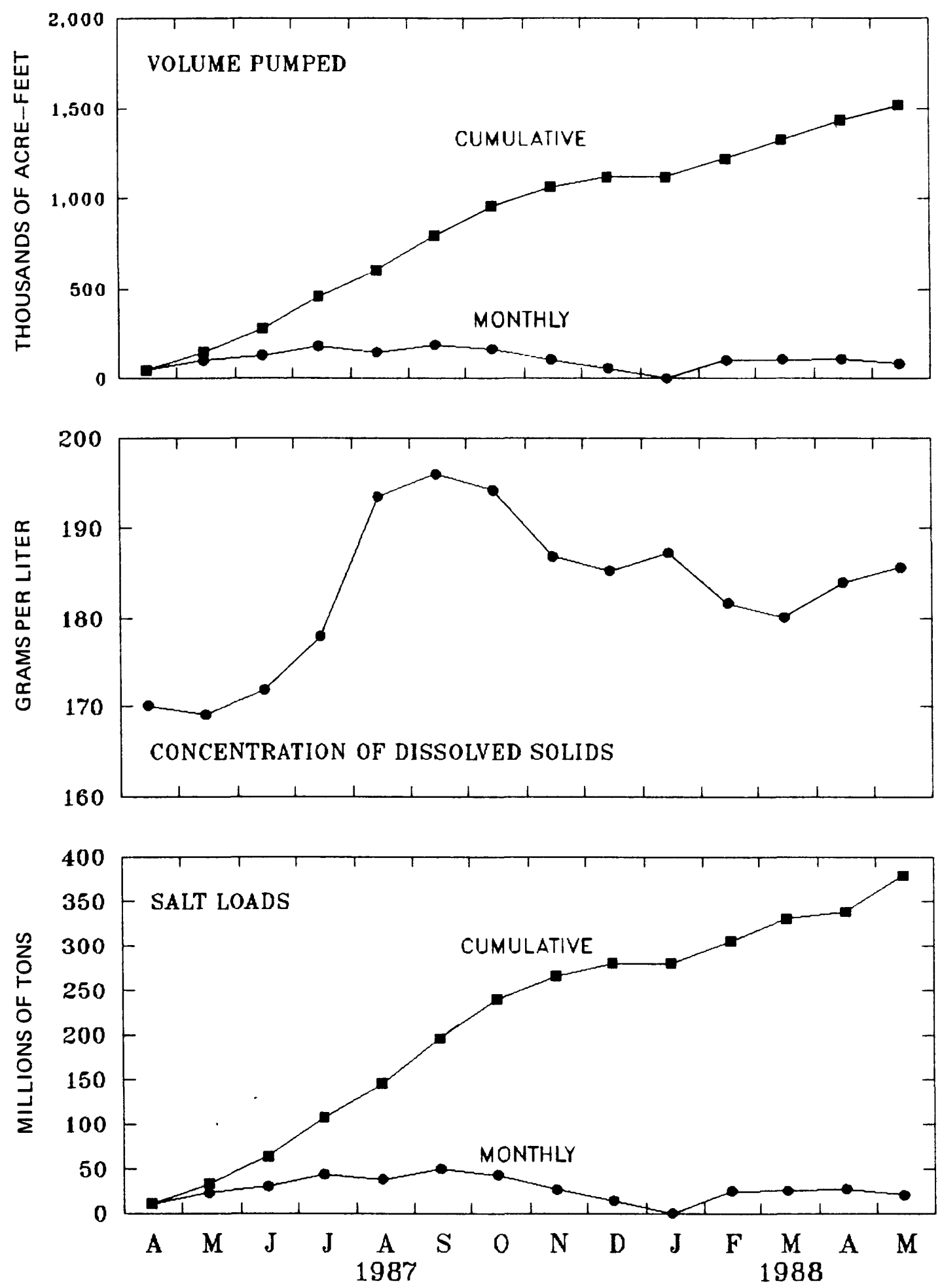

Figure 3.--Volumes, concentration of dissolved solids, and salt loads of brine pumped from Great Salt Lake into West Pond, April 1987 to May 1988. 
The largest tonnage of salts included in the budget calculations is from pumpage into the pond. The accuracy of the pumpage estimates was not evaluated; however, a 5 percent error in pumpage estimates would result in an error of 16.7 million tons of salt in the budget. If the pumpage was overestimated by 5 percent, then the total quantity of salt pumped into the pond would be about 317 million tons, and if underestimated by 5 percent, the total quantity of salt pumped would be 351 million tons.

The quantity of salt dissolved in Great Salt Lake prior to the pumping project was estimated to be about 4.9 billion tons. Thus, the quantity of salt pumped from Great Salt Lake into West Pond during April 10, 1987, to April 6, 1988, was about 6.5 to 7.2 percent of the salt contained in the lake.

\section{Storage in West Pond}

Once the brine enters West Pond, it begins to concentrate as water is evaporated. The salinity is smallest to the north where the pumped brine enters from the canal, and it is largest at the southern end and at the weir in the Newfoundland Dike. During the hot summer months when the concentration of dissolved solids exceeds about 355 grams per liter, halite (sodium chloride) will precipitate onto the bottan of the pond. Ideally, the halite will dissolve into the less concentrated water that is pumped into the pond. During the cold winter months, mirabilite, a hydrated sodium sulfate, will precipitate when the brine temperature drops below about 3 degrees celsius (the solubility temperature varies, depending upon the concentration of dissolved solids) and will dissolve as the brines warm again in the spring.

West Pond has been sampled twice for the purpose of computing the quantity of salts stored in the pond. The first sampling was carried out by EWP using a helicopter overflight on December 10, 1987, and the second was from an air boat by the USGS and UGS during April 4-6, 1988.

During April 4-6, 1988, field measurements for temperature and specific gravity were made, and samples were collected at 24 sites on West Pond (fig. 4). The location for each site was determined through the use of an electronic-sensing instrument for remote determination of latitude and longitude, and a USGS map, scale 1:100,000, showing the bathymetric contours of the bottom of the pond (Chapman and Sappington, 1986).

Sampling sites were selected along eight approximate east-west 1 ines through the sections of West Pond (fig. 4). Specific gravity and temperature measurements were made at the surface and bottom of West Pond where depths were greater than 2 feet and at the surface only when depiths were less than 2 feet. Measurements also were made at intermediate depths at each site if there were substantial differences between the surface and bottom measurements of specific gravity. Samples for chemical analysis also were collected at selected sites and depths; 23 samples were selected and analyzed for major ions (table 3 ). West pond was divided into 10 sections for the purpose of calculating the salt load.

It is believed that no halite was deposited on the pond floor at the times West Pond was sampled. During the December 1987 and April 1988 sampling periods, the maximum observed concentration of dissolved solids was less than the saturation concentration of 355 grams per liter at which sodium chloride 


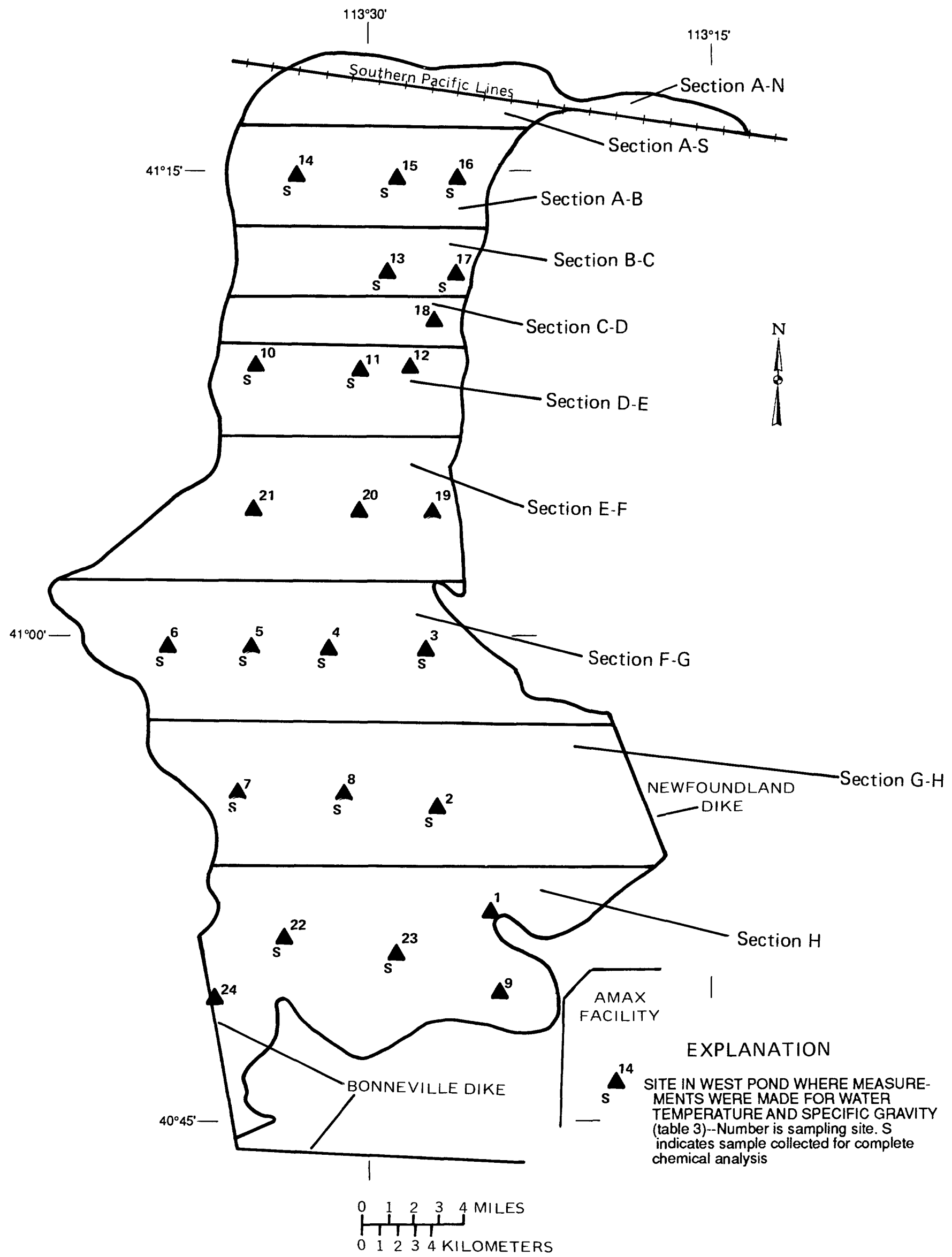

Figure 4.--West Pond sampling sites and section divisions used for computing salt loads, April 4-6, 1988. 
Table 3.-Chemical analyses and field measurements of temperature and specific gravity for West Pond, April 4-6, 1988

$\left[{ }^{\circ} \mathrm{C}\right.$, degrees Celsius; $\mathrm{mg} / \mathrm{L}$, milligrams per liter;

$\mathrm{g} / \mathrm{ml}$, grams per milliliter; --, no data]

Sampling site: See figure 1 for site location.

\begin{tabular}{|c|c|c|c|c|c|c|c|c|c|c|c|c|c|}
\hline $\begin{array}{l}\text { Samp- } \\
\text { ling } \\
\text { site }\end{array}$ & Date & $\begin{array}{l}\text { Water } \\
\text { temper- } \\
\text { ature } \\
\text { (C) }\end{array}$ & $\begin{array}{l}\text { Calcium, } \\
\text { total } \\
\text { recov- } \\
\text { erable } \\
\text { (mg/L } \\
\text { as Ca) }\end{array}$ & $\begin{array}{l}\text { Magne- } \\
\text { sium, } \\
\text { total } \\
\text { recov- } \\
\text { erable } \\
\text { (mg/L } \\
\text { as } \mathrm{kg})\end{array}$ & $\begin{array}{l}\text { Sodium, } \\
\text { total } \\
\text { recov- } \\
\text { erable } \\
\text { (mg/L } \\
\text { as } \mathrm{Na} \text { ) }\end{array}$ & $\begin{array}{l}\text { Potas- } \\
\text { sium, } \\
\text { total } \\
\text { recov- } \\
\text { erable } \\
\text { (mg/L } \\
\text { as K) }\end{array}$ & $\begin{array}{l}\text { Chlo- } \\
\text { ride, } \\
\text { dis- } \\
\text { solved } \\
\text { (mg/L } \\
\text { as (1) }\end{array}$ & $\begin{array}{c}\text { Sulfate, } \\
\text { dis- } \\
\text { solved } \\
\text { (mg/L } \\
\left.\text { as } \mathrm{SO}_{4}\right)\end{array}$ & $\begin{array}{l}\text { Solids, } \\
\text { residue } \\
\text { at } \\
180^{\circ} \mathrm{C} \text {, } \\
\text { dis- } \\
\text { solved } \\
(\mathrm{mg} / \mathrm{L})\end{array}$ & $\begin{array}{c}\text { Density, } \\
(g / m 1 \\
\text { at } \\
\left.20{ }^{\circ} \mathrm{C}\right)\end{array}$ & $\begin{array}{c}\text { Spe- } \\
\text { cific } \\
\text { gravity }\end{array}$ & $\begin{array}{l}\text { Depth } \\
\text { at } \\
\text { sample } \\
\text { loc- } \\
\text { at ion, } \\
\text { total } \\
\text { (feet) }\end{array}$ & $\begin{array}{c}\text { Depth } \\
\text { of } \\
\text { lake, } \\
\text { maximum } \\
\text { (feet) }\end{array}$ \\
\hline $\begin{array}{l}1 \\
2 \\
3 \\
4\end{array}$ & $\begin{array}{l}04-05-88 \\
04-05-88 \\
04-05-88 \\
04-05-88 \\
04-05-88\end{array}$ & $\begin{array}{l}11.5 \\
12.5 \\
12.5 \\
12.0 \\
12.0\end{array}$ & $\begin{array}{r}620 \\
660 \\
-- \\
630\end{array}$ & $\begin{array}{c}5, \overline{-} \\
5,800 \\
5, \overline{800}\end{array}$ & $\begin{array}{l}76,000 \\
65,000 \\
65,000\end{array}$ & $\begin{array}{c}2, \overline{600} \\
3,000 \\
-\overline{-} \\
2,400\end{array}$ & $\begin{array}{c}140,-000 \\
36,000 \\
\overline{--} \\
130,000\end{array}$ & $\begin{array}{l}16,000 \\
16,000 \\
\overline{-} \\
15,000\end{array}$ & $\begin{array}{l}255,000 \\
256,000 \\
-- \\
245,000\end{array}$ & $\begin{array}{l}1.173 \\
1.167 \\
1.168 \\
1.168 \\
1.160\end{array}$ & $\begin{array}{l}1.178 \\
1.172 \\
1.173 \\
1.172 \\
1.165\end{array}$ & $\begin{array}{l}0.50 \\
0.50 \\
0.50 \\
2.30 \\
0.50\end{array}$ & $\begin{array}{l}0.50 \\
1.50 \\
2.30 \\
2.30 \\
4.00\end{array}$ \\
\hline $\begin{array}{l}5 \\
6\end{array}$ & $\begin{array}{l}04-05-88 \\
04-05-88 \\
04-05-88 \\
04-05-88 \\
04-05-88\end{array}$ & $\begin{array}{l}11.5 \\
12.5 \\
11.0 \\
11.0 \\
12.0\end{array}$ & $\begin{array}{l}700 \\
660 \\
620 \\
-- \\
600\end{array}$ & $\begin{array}{l}6,100 \\
5,200 \\
5,300 \\
5,-- \\
500\end{array}$ & $\begin{array}{c}64,000 \\
67,000 \\
58,000 \\
54,000\end{array}$ & $\begin{array}{c}2,600 \\
2,400 \\
2,500 \\
2,-- \\
2,400\end{array}$ & $\begin{array}{c}120,000 \\
130,000 \\
140,000 \\
130,-000\end{array}$ & $\begin{array}{l}15,000 \\
15,000 \\
15,000 \\
15,-000\end{array}$ & $\begin{array}{l}246,000 \\
246,000 \\
245,000 \\
-- \\
243,000\end{array}$ & $\begin{array}{l}1.161 \\
1.161 \\
1.161 \\
1.156 \\
1.159\end{array}$ & $\begin{array}{l}1.167 \\
1.166 \\
1.166 \\
1.161 \\
1.164\end{array}$ & $\begin{array}{l}4.00 \\
0.50 \\
5.00 \\
0.50 \\
2.50\end{array}$ & $\begin{array}{l}4.00 \\
5.00 \\
5.00 \\
2.50 \\
2.50\end{array}$ \\
\hline $\begin{array}{r}7 \\
8 \\
9 \\
10\end{array}$ & $\begin{array}{l}04-05-88 \\
04-05-88 \\
04-05-88 \\
04-05-88 \\
04-06-88\end{array}$ & $\begin{array}{l}12.5 \\
11.5 \\
11.5 \\
15.5 \\
10.0\end{array}$ & $\begin{array}{l}550 \\
-\overline{650} \\
\overline{--}\end{array}$ & $\begin{array}{c}5,400 \\
5,-- \\
500 \\
4,-\overline{900}\end{array}$ & $\begin{array}{c}64,000 \\
65,-000 \\
49, \overline{-} \\
4900\end{array}$ & $\begin{array}{c}2,400 \\
2, \overline{-} \\
1, \overline{-\overline{90}}\end{array}$ & $\begin{array}{c}130,000 \\
\overline{--} \\
110,000 \\
110,-000\end{array}$ & $\begin{array}{c}15,000 \\
-- \\
15,000 \\
-- \\
13,000\end{array}$ & $\begin{array}{l}248,000 \\
242,000 \\
-\overline{2} \\
225,000\end{array}$ & $\begin{array}{l}1.163 \\
1.159 \\
1.159 \\
1.177 \\
1.148\end{array}$ & $\begin{array}{l}1.167 \\
1.164 \\
1.164 \\
1.180 \\
1.153\end{array}$ & $\begin{array}{l}0.50 \\
0.50 \\
2.50 \\
0.50 \\
0.50\end{array}$ & $\begin{array}{l}2.00 \\
2.50 \\
2.50 \\
1.10 \\
2.40\end{array}$ \\
\hline 11 & $\begin{array}{l}04-06-88 \\
04-06-88 \\
04-06-88 \\
04-06-88 \\
04-06-88\end{array}$ & $\begin{array}{c}10.5 \\
11.0 \\
-- \\
-- \\
--\end{array}$ & $\begin{array}{r}650 \\
-- \\
-- \\
--\end{array}$ & $\begin{array}{c}6,100 \\
-- \\
-- \\
--\end{array}$ & $\begin{array}{c}63,000 \\
-- \\
-- \\
--\end{array}$ & $\begin{array}{c}2,-\overline{400} \\
-- \\
-- \\
--\end{array}$ & $\begin{array}{c}130,000 \\
-- \\
-- \\
--\end{array}$ & $\begin{array}{c}-- \\
13,000 \\
-- \\
-- \\
--\end{array}$ & $\begin{array}{c}225,000 \\
- \\
-- \\
-\end{array}$ & $\begin{array}{l}\overline{-} \\
\overline{-} \\
- \\
-\end{array}$ & $\begin{array}{l}1.153 \\
1.153 \\
1.154 \\
1.158 \\
1.159\end{array}$ & $\begin{array}{l}2.40 \\
0.50 \\
1.00 \\
2.00 \\
3.00\end{array}$ & $\begin{array}{l}2.40 \\
4.80 \\
4.80 \\
4.80 \\
4.80\end{array}$ \\
\hline $\begin{array}{l}12 \\
13\end{array}$ & $\begin{array}{l}04-06-88 \\
04-06-88 \\
04-06-88 \\
04-06-88 \\
04-06-88\end{array}$ & $\begin{array}{l}11.5 \\
12.0 \\
12.0 \\
12.0 \\
12.0\end{array}$ & $\begin{array}{r}600 \\
-- \\
450 \\
--\end{array}$ & $\begin{array}{c}5,200 \\
-- \\
\overline{--} \\
4,800 \\
--\end{array}$ & $\begin{array}{c}68,000 \\
-- \\
\overline{--} \\
62,000 \\
--\end{array}$ & $\begin{array}{c}2,500 \\
-- \\
2,200 \\
--\end{array}$ & $\begin{array}{c}130,000 \\
-- \\
120,000 \\
--\end{array}$ & $\begin{array}{c}14,000 \\
-- \\
\overline{13,000} \\
--\end{array}$ & $\begin{array}{c}234,000 \\
\overline{-} \\
218,000 \\
-\end{array}$ & $\begin{array}{c}1.154 \\
1.154 \\
1.154 \\
1.143 \\
--\end{array}$ & $\begin{array}{l}1.159 \\
1.159 \\
1.159 \\
1.148 \\
1.150\end{array}$ & $\begin{array}{l}4.50 \\
0.50 \\
3.80 \\
0.50 \\
1.00\end{array}$ & $\begin{array}{l}4.80 \\
3.80 \\
3.80 \\
6.30 \\
6.30\end{array}$ \\
\hline 14 & $\begin{array}{l}04-06-88 \\
04-06-88 \\
04-06-88 \\
04-06-88 \\
04-06-88\end{array}$ & $\begin{array}{l}12.0 \\
11.5 \\
12.5 \\
12.5 \\
12.0\end{array}$ & $\begin{array}{l}-- \\
-- \\
360 \\
490\end{array}$ & $\begin{array}{c}-- \\
-- \\
4,-- \\
5,300\end{array}$ & $\begin{array}{c}-- \\
\overline{-} \\
61,000 \\
55,000\end{array}$ & $\begin{array}{c}-- \\
-- \\
2,- \\
2,400 \\
2,400\end{array}$ & $\begin{array}{c}-- \\
-- \\
110,000 \\
130,000\end{array}$ & $\begin{array}{c}-- \\
-- \\
12,000 \\
13,000\end{array}$ & $\begin{array}{c}\bar{z} \\
\bar{z} \\
200,000 \\
216,000\end{array}$ & $\begin{array}{l}-- \\
\overline{1.150} \\
1.132 \\
1.147\end{array}$ & $\begin{array}{l}1.152 \\
1.155 \\
1.155 \\
1.136 \\
1.147\end{array}$ & $\begin{array}{l}2.00 \\
4.00 \\
6.30 \\
0.50 \\
3.00\end{array}$ & $\begin{array}{l}6.30 \\
6.30 \\
6.30 \\
3.00 \\
3.00\end{array}$ \\
\hline 15 & $\begin{array}{l}04-06-88 \\
04-06-88 \\
04-06-88 \\
04-06-88 \\
04-06-88\end{array}$ & $\begin{array}{r}13.0 \\
12.5 \\
12.0 \\
13.5\end{array}$ & $\begin{array}{r}420 \\
-- \\
500 \\
370\end{array}$ & $\begin{array}{c}4,700 \\
-- \\
-- \\
5,100 \\
4,700\end{array}$ & $\begin{array}{c}61,000 \\
\overline{-} \\
60,000 \\
53,000\end{array}$ & $\begin{array}{c}2,200 \\
-- \\
-\overline{-} \\
2,700 \\
2,400\end{array}$ & $\begin{array}{c}110,000 \\
-- \\
-- \\
110,000 \\
120,000\end{array}$ & $\begin{array}{c}13,000 \\
-- \\
12,000 \\
12,000\end{array}$ & $\begin{array}{l}213,000 \\
\overline{-} \\
218,000 \\
206,000\end{array}$ & $\begin{array}{l}1.140 \\
-- \\
\overline{1.143} \\
1.136\end{array}$ & $\begin{array}{l}1.145 \\
1.145 \\
1.146 \\
1.148 \\
1.139\end{array}$ & $\begin{array}{l}0.50 \\
1.00 \\
2.00 \\
3.50 \\
0.50\end{array}$ & $\begin{array}{l}4.00 \\
4.00 \\
4.00 \\
4.00 \\
2.50\end{array}$ \\
\hline 17 & $\begin{array}{l}04-06-88 \\
04-06-88 \\
04-06-88 \\
04-06-88 \\
04-06-88\end{array}$ & $\begin{array}{l}12.5 \\
13.5 \\
13.5 \\
14.0 \\
14.0\end{array}$ & $\begin{array}{l}-- \\
-- \\
460 \\
--\end{array}$ & $\begin{array}{l}-- \\
-- \\
5, \overline{100} \\
--\end{array}$ & $\begin{array}{c}-- \\
-- \\
\overline{--}, 000 \\
--\end{array}$ & $\begin{array}{c}-- \\
-- \\
2,300 \\
--\end{array}$ & $\begin{array}{c}-- \\
120,000 \\
--\end{array}$ & $\begin{array}{c}-- \\
-- \\
13,000 \\
--\end{array}$ & $\begin{array}{c}\overline{-} \\
\overline{218,000}\end{array}$ & $\begin{array}{l}-- \\
\overline{1.140} \\
1.144 \\
1.144\end{array}$ & $\begin{array}{l}1.141 \\
1.144 \\
1.144 \\
1.148 \\
1.148\end{array}$ & $\begin{array}{l}1.00 \\
2.00 \\
2.50 \\
0.50 \\
2.00\end{array}$ & $\begin{array}{l}2.50 \\
2.50 \\
2.50 \\
2.20 \\
2.20\end{array}$ \\
\hline $\begin{array}{l}18 \\
19 \\
20\end{array}$ & $\begin{array}{l}04-06-88 \\
04-06-88 \\
04-06-88 \\
04-06-88 \\
04-06-88\end{array}$ & $\begin{array}{l}14.0 \\
14.0 \\
14.5 \\
14.5 \\
13.0\end{array}$ & $\begin{array}{c}-- \\
-- \\
-- \\
640\end{array}$ & $\begin{array}{c}-- \\
-- \\
-- \\
\overline{-500}\end{array}$ & $\begin{array}{c}-- \\
\overline{-} \\
\overline{66,000}\end{array}$ & $\begin{array}{c}-- \\
-- \\
-- \\
2,700\end{array}$ & $\begin{array}{c}-- \\
-- \\
-- \\
96,000\end{array}$ & $\begin{array}{c}-- \\
15,000\end{array}$ & $\begin{array}{c}\overline{-} \\
\bar{z} \\
238,000\end{array}$ & $\begin{array}{l}1.150 \\
\overline{1.156} \\
1.156 \\
1.157\end{array}$ & $\begin{array}{l}1.154 \\
1.154 \\
1.160 \\
1.160 \\
1.161\end{array}$ & $\begin{array}{l}0.50 \\
2.50 \\
0.50 \\
2.00 \\
0.50\end{array}$ & $\begin{array}{l}2.50 \\
2.50 \\
2.00 \\
2.00 \\
5.50\end{array}$ \\
\hline
\end{tabular}


Table 3.-Chemical analyses and field measurements of temperature and specific gravity for West Pond, April 4-6, 1988--Continued

\begin{tabular}{|c|c|c|c|c|c|c|c|c|c|c|c|c|c|}
\hline $\begin{array}{l}\text { Samp- } \\
\text { ling } \\
\text { site }\end{array}$ & Date & $\begin{array}{l}\text { Water } \\
\text { temper- } \\
\text { ature } \\
\text { (c) }\end{array}$ & $\begin{array}{l}\text { Calcium, } \\
\text { total } \\
\text { recov- } \\
\text { erable } \\
\text { (mg/L } \\
\text { as Ca) }\end{array}$ & $\begin{array}{l}\text { Magne- } \\
\text { sium, } \\
\text { total } \\
\text { recov- } \\
\text { erable } \\
\text { (mg/h } \\
\text { as Mg) }\end{array}$ & $\begin{array}{l}\text { Sodium, } \\
\text { total } \\
\text { recov- } \\
\text { erable } \\
\text { (mg/L } \\
\text { as Na) }\end{array}$ & $\begin{array}{l}\text { Potas- } \\
\text { sium, } \\
\text { total } \\
\text { recov- } \\
\text { erable } \\
\text { (mg/L } \\
\text { as K) }\end{array}$ & $\begin{array}{l}\text { Chlo- } \\
\text { ride, } \\
\text { dis- } \\
\text { solved } \\
\text { (mg/L } \\
\text { as (l) }\end{array}$ & $\begin{array}{l}\text { Sulfate, } \\
\text { dis- } \\
\text { solved } \\
\text { (mg/L } \\
\text { as } \mathrm{SO}_{4} \text { ) }\end{array}$ & $\begin{array}{l}\text { Solids, } \\
\text { residue } \\
\text { at } \\
180^{\circ} \mathrm{C} \text {, } \\
\text { dis- } \\
\text { solved } \\
\text { (mg/L) }\end{array}$ & $\begin{array}{c}\text { Density, } \\
(\mathrm{g} / \mathrm{m}) \\
\left.20{ }^{\mathrm{at}} \mathrm{C}\right)\end{array}$ & $\begin{array}{c}\text { Spe- } \\
\text { cific } \\
\text { gravity }\end{array}$ & $\begin{array}{l}\text { Depth } \\
\text { at } \\
\text { sample } \\
\text { loc- } \\
\text { ation, } \\
\text { total } \\
\text { (feet) }\end{array}$ & $\begin{array}{l}\text { Depth } \\
\text { of } \\
\text { lake, } \\
\text { maximim } \\
\text { (feet) }\end{array}$ \\
\hline 20 & $\begin{array}{l}04-06-88 \\
04-06-88 \\
04-06-88 \\
04-06-88 \\
04-06-88\end{array}$ & $\begin{array}{l}11.0 \\
10.5 \\
11.0 \\
13.5 \\
12.0\end{array}$ & $\begin{array}{c}-- \\
660 \\
-- \\
--\end{array}$ & $\begin{array}{c}-- \\
5, \overline{700} \\
-- \\
--\end{array}$ & $\begin{array}{c}-- \\
\overline{--} \\
65,000 \\
-- \\
--\end{array}$ & $\begin{array}{c}-- \\
2, \overline{600} \\
-- \\
--\end{array}$ & $\begin{array}{c}-- \\
120,000 \\
-- \\
--\end{array}$ & $\begin{array}{c}-- \\
14,000 \\
-- \\
--\end{array}$ & $\begin{array}{c}-- \\
23 \overline{7}, 000 \\
-- \\
--\end{array}$ & $\begin{array}{l}-- \\
1 . \overline{157} \\
1.151 \\
--\end{array}$ & $\begin{array}{l}1.162 \\
1.162 \\
1.162 \\
1.155 \\
1.156\end{array}$ & $\begin{array}{l}2.00 \\
3.00 \\
4.50 \\
0.50 \\
2.00\end{array}$ & $\begin{array}{l}5.50 \\
5.50 \\
5.50 \\
3.50 \\
3.50\end{array}$ \\
\hline $\begin{array}{l}22 \\
23 \\
24\end{array}$ & $\begin{array}{l}04-06-88 \\
04-06-88 \\
04-06-88 \\
04-06-88 \\
04-06-88\end{array}$ & $\begin{array}{l}13.0 \\
13.5 \\
17.5 \\
15.5 \\
-.\end{array}$ & $\begin{array}{r}-- \\
630 \\
620 \\
--\end{array}$ & $\begin{array}{c}-- \\
\overline{--} \\
6,000 \\
5,900 \\
--\end{array}$ & $\begin{array}{c}\overline{-} \\
\overline{-} \\
71,000 \\
72,000 \\
--\end{array}$ & $\begin{array}{c}-- \\
\overline{--} \\
2,800 \\
2,900 \\
--\end{array}$ & $\begin{array}{c}-- \\
100,000 \\
6,100 \\
--\end{array}$ & $\begin{array}{c}-- \\
\overline{--} \\
17,000 \\
--\end{array}$ & $\begin{array}{c}-- \\
263,000 \\
270,000 \\
--\end{array}$ & $\begin{array}{l}\overline{1.159} \\
1.173 \\
1.177 \\
1.195\end{array}$ & $\begin{array}{l}1.162 \\
1.163 \\
1.175 \\
1.180 \\
--\end{array}$ & $\begin{array}{l}2.50 \\
3.00 \\
0.50 \\
0.50 \\
0.10\end{array}$ & $\begin{array}{l}3.50 \\
3.50 \\
1.00 \\
1.50 \\
0.30\end{array}$ \\
\hline
\end{tabular}

(halite) begins to precipitate in Great Salt Lake. During December 1987, the maximum observed concentration of dissolved solids was about 252 grams per liter (Karen Nichols, Eckhoff, Watson, and Preator Engineering, written commun., 1988), and during April 1988, the maximum observed concentration was 270 grams per liter (table 3). Also during April 1988, no deposits of halite were observed at any of the sampling sites. It is probable, however, that mi rabilite was present during December 1987, especially in the southern part of West Pond containing the more concentrated brines.

The salt load contained in West Pond was determined by computing the loads for each section of the pond. Because there was vertical stratification, incremental loads for one-foot sublayers were computed within each section. This required determining the volume and average concentration of dissolved solids in each sublayer. The average concentration of dissolved solids was determined from specific gravity or density using the relation shown in figure 5.

The volume of each sublayer for each section was computed by digitizing the areas defined by the bathymetric contours on the 1:100,000 scale map and then preparing elevation-volume relations for each section (fig. 6). The salt load for a sublayer then was computed from the product of the concentration of dissolved solids and the volume of a sublayer (table 6).

The salt load for each section was then calculated from the sum of the sublayer loads, the loads for all sections were summed, and it was determined that 189 million tons of dissolved salt were contained in West Pond during April 4-6, 1988 (table 4). The salt stored in west Pond is about 56 percent of the quantity of salt in brine pumped from Great Salt Lake. 


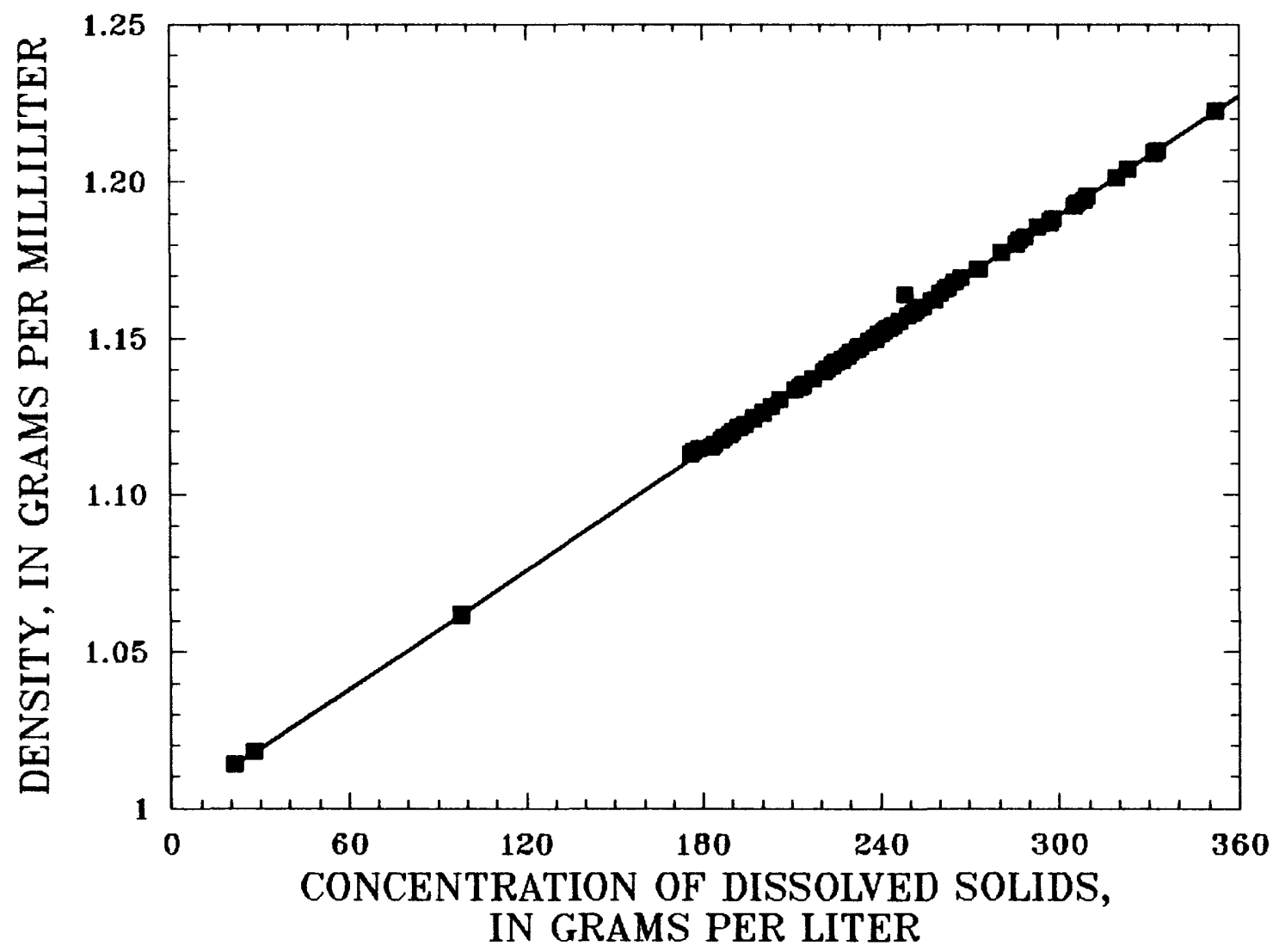

Figure 5.--Relation of density and concentration of dissolved solids in brine for West Pond.

EWP prepared elevation-volume relations from map imagery that showed larger volumes than were computed using the USGS map. The elevation-volume curve prepared by EWP shows that at an elevation of $4,216.35$ feet, the volume is 727,000 acre-feet. The curve prepared from the USGS map shows a volume of 586,000 acre-feet, or a difference of about 24 percent. This 24 percent increase in brine volume increased the salt load to about $240 \mathrm{milli}$ ion tons, which is about 72 percent of the quantity of salt pumped into West Pond during April 10, 1987, to April 6, 1988.

For the sampling in December 1987, a similar procedure was used to compute salt loads, except that west Pond was divided into 5 sections (fig. 7) instead of 10 for purposes of computing tonnages of salt. Also, there was no subdivision into incremental sublayers. The salinity of the brine for each of the five pond segments was calculated by averaging the salinity values of the surface and bottom samples that were collected within each section. The total salt load computed for the sampling in December was 184 million tons (table 5). 

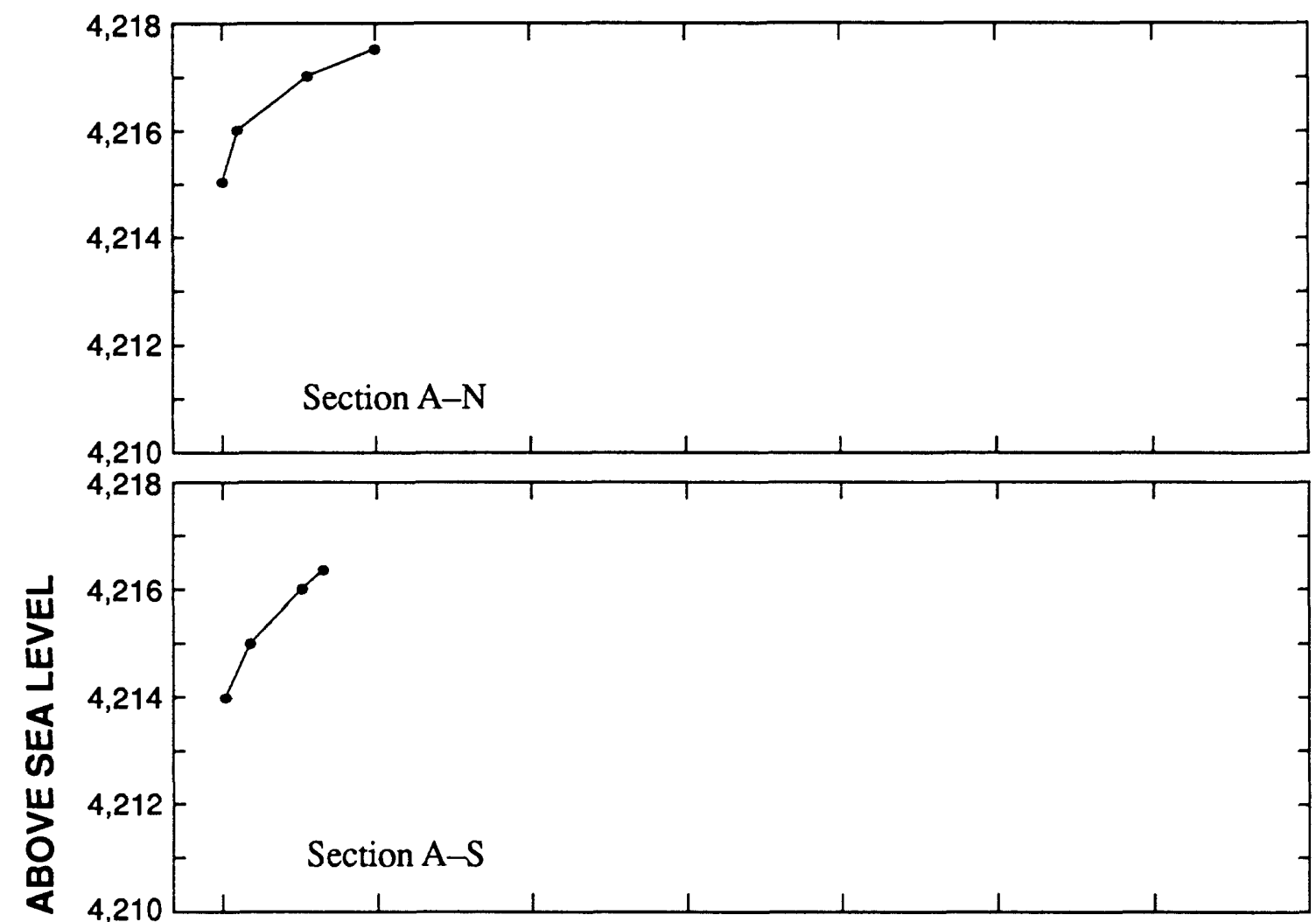

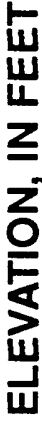
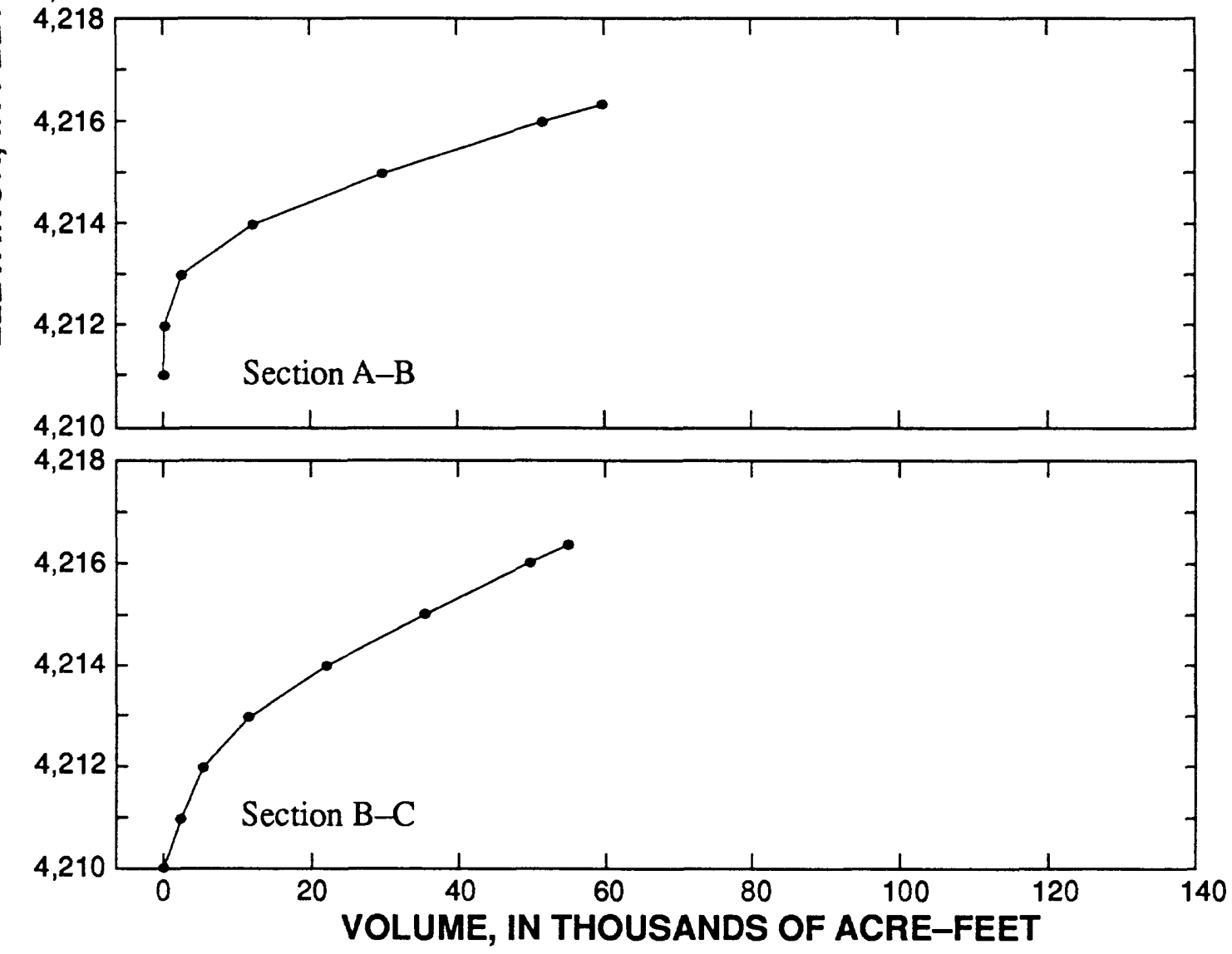

Figure 6.--Elevation-volume relation for sections of West Pond. 


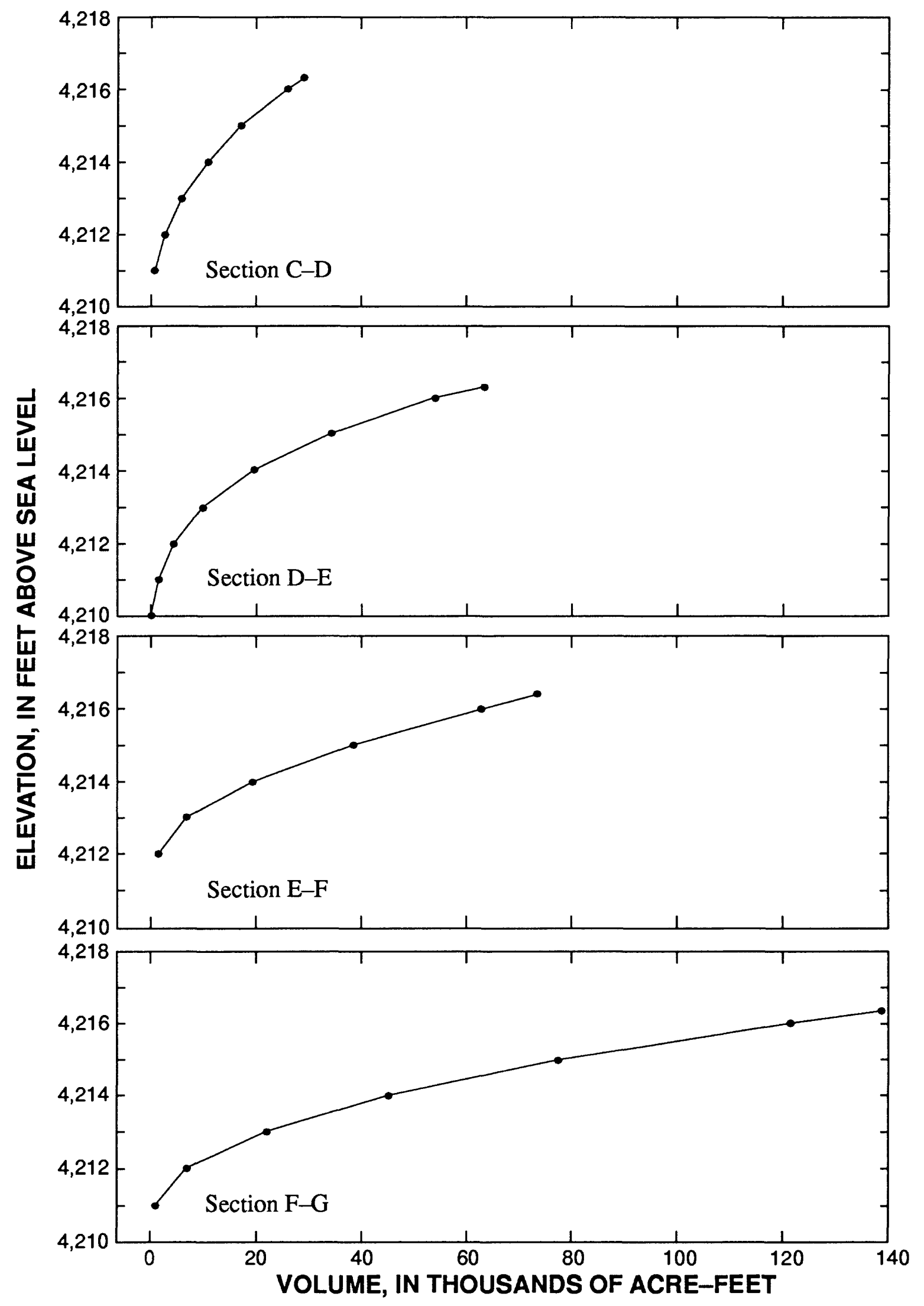

Figure 6.--Elevation-volume relation for sections of West Pond-Continued. 


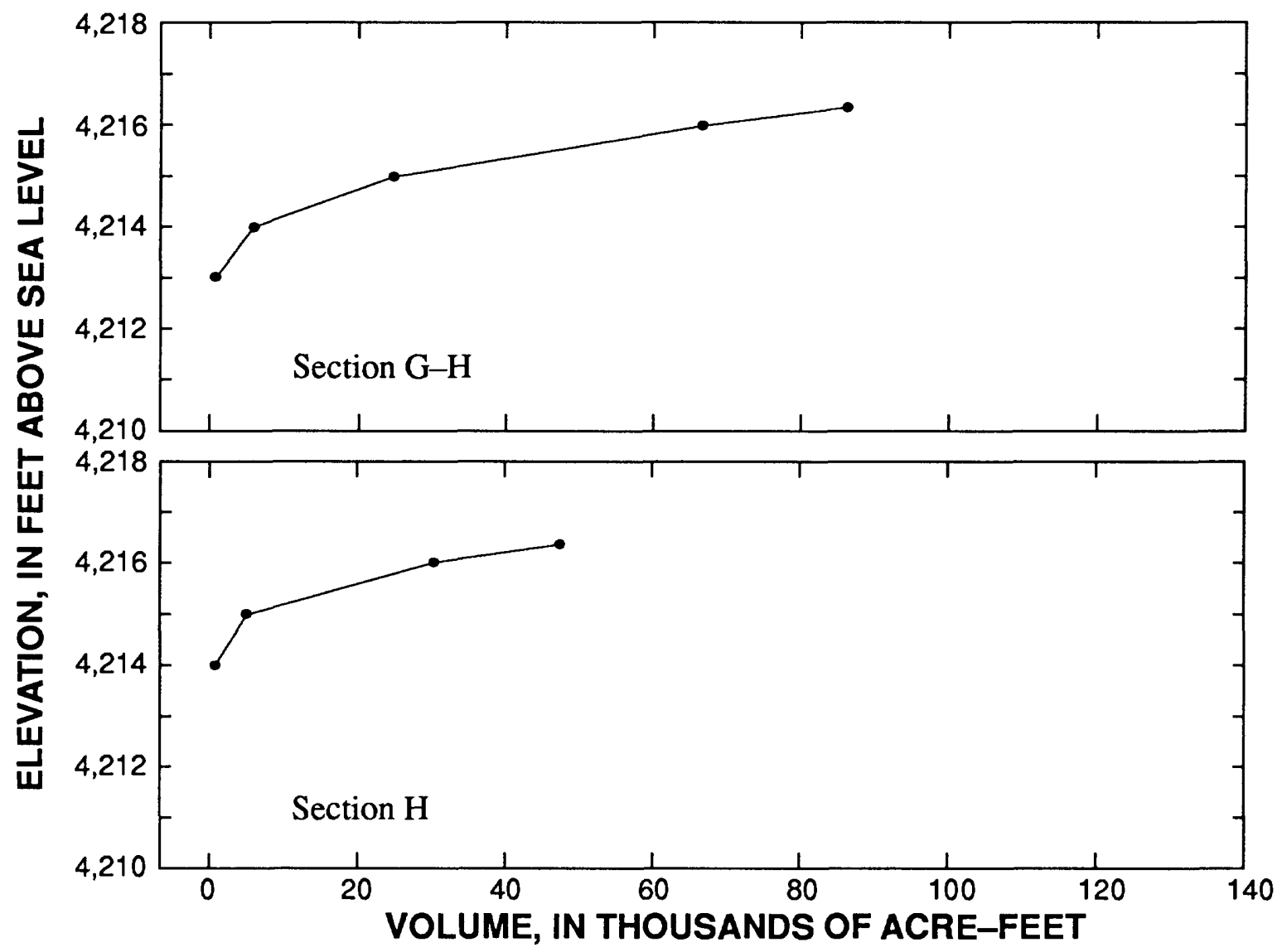

Figure 6.--Elevation-volume relation for sections of West Pond-Continued.

Table 4.--Summary of volume of brine and tons of salt for sections of West Pond, April 4-6, 1988

[Section: See text for explanation of numbering system of sections]

\begin{tabular}{lcc}
\hline Section & $\begin{array}{c}\text { Volume } \\
\text { (acre-feet) }\end{array}$ & $\begin{array}{c}\text { Salt load } \\
\text { (tons) }\end{array}$ \\
\hline A-N & $19,922.00$ & $5,496,750$ \\
A-S & $13,000.90$ & $3,654,870$ \\
A-B & $59,942.91$ & $17,207,603$ \\
B-C & $55,124.67$ & $16,629,743$ \\
C-D & $28,460.71$ & $8,805,918$ \\
D-E & $63,425.63$ & $19,975,047$ \\
E-F & $73,974.55$ & $24,012,177$ \\
F-G & $138,382.50$ & $46,673,650$ \\
G-H & $86,508.12$ & $29,330,341$ \\
H & $47,711.84$ & $17,209,001$ \\
\hline TOTAL & $586,000.00$ & $189,000,000$ \\
(rounded) & & \\
\hline
\end{tabular}




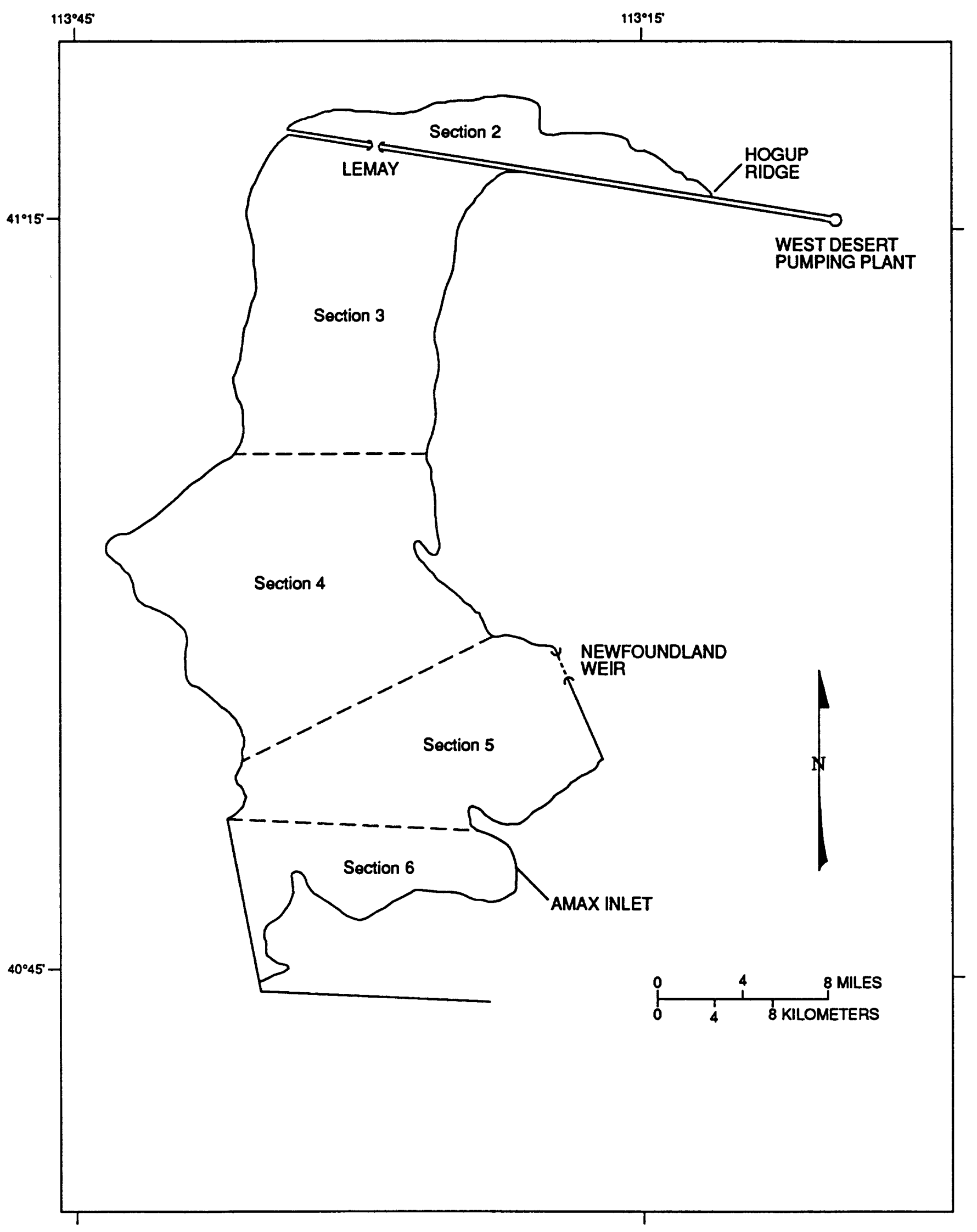

Figure 7.--West Pond sections used for computing salt loads, December 10, 1987. 
Table 5. - Summary of volume of brine and tons of salt for sections of West Pond, December 10, 1987

Section: See figure 7 for numbering system of sections. Elevation: In feet above sea level.

\begin{tabular}{ccccc}
\hline Section & $\begin{array}{c}\text { Elevation } \\
\text { (feet) }\end{array}$ & $\begin{array}{c}\text { Volume } \\
\text { (acre-feet) }\end{array}$ & $\begin{array}{c}\text { Concentration } \\
\text { (grams/liter) }\end{array}$ & $\begin{array}{c}\text { Salt load } \\
\text { (tons) }\end{array}$ \\
\hline 2 & 4217.5 & 20,000 & 185 & $5,000,000$ \\
3 & 4216.2 & 197,700 & 219 & $58,700,000$ \\
4 & 4216.2 & 245,000 & 248 & $82,400,000$ \\
5 & 4216.2 & 79,900 & 252 & $27,300,000$ \\
6 & 4216.2 & 32,500 & 241 & $10,600,000$ \\
Total (rounded) & 575,000 & & $184,000,000$
\end{tabular}

\section{Subsurface Storage}

The unsaturated sediments beneath the floor of West Pond probably became saturated during the filling of West Pond. The quantity of salt stored in the subsurface sediments depends on the depth to the water table before purming began, the inundated area, the specific yield of the sediments, and the salinity of the brine infiltrating the sediments.

Using water levels obtained during the drilling of test holes prior to construction of the dikes (Eckhoff, Watson, and Preator Engineering, and Dames and Moore, 1985) and from monitoring wells near the dikes about 2 months after the pond began filling, the depth to the water table was estimated to range from about 0.5 to 1.1 feet. Depth to ground water near the north end of West Pond is not known, and could be a relatively minor source of error for the salt budget. The land surface at the north end of West Pond is 2 to 3 feet lower than the land surface at the south end and the water table probably slopes slightly to the north; however, the depth to water should be about the same or less than at the south end.

Data from Johnson (1967) indicate that specific yield of sediments similar to those in the Great Salt Lake Desert should range from about 5 to 10 percent. The salinity of the brine that seeped into the subsurface beneath West Pond was assumed to be the weighted average concentration computed from sampling on hest Pond during April 4-6, 1988, which was 240 grams per liter. The area inundated by West Pond was estimated to be about 277,000 acres, so the total salt load that seeped into the sediments ranged from 4,500,000 (using an unsaturated thickness of 0.5 foot) to $9,900,000$ tons (using unsaturated thickness of 1.1 feet, see compilation on next page) and represents 1.3 to 3 percent of the quantity of salt pumped from Great Salt Lake. 


\begin{tabular}{|c|c|c|c|c|}
\hline $\begin{array}{l}\text { Area } \\
\text { (acres) }\end{array}$ & $\begin{array}{l}\text { Concentration } \\
\text { (grams/liter) }\end{array}$ & $\begin{array}{l}\text { Unsaturated } \\
\text { thickness } \\
\text { (feet) }\end{array}$ & $\begin{array}{l}\text { Specific } \\
\text { yield }\end{array}$ & $\begin{array}{l}\text { Salt load, in tons } \\
\text { Using Using } \\
\text { unsaturated unsaturated } \\
\text { thickness thickness } \\
\text { of } 0.5 \mathrm{ft} \text { of } 1.1 \mathrm{ft}\end{array}$ \\
\hline 277,000 & 240 & $0.5-1.1$ & 0.10 & $9,900,000$ \\
\hline
\end{tabular}

Withdrawals by American Magnesium Corporation (AMAX)

On January 21, 1988, AMAX began purming brine from West Pond into a 54,000-acre solar evaporation complex. Pumping records supplied to EWP by AMAX indicate that about 42,000 acre-feet of brine was pumped from West Pond into their system during January 21 to April 6, 1988 (fig. 8).

The average monthly concentration of dissolved solids (fig. 8) of the brine being pumped by AMAX was calculated from frequent density measurements. The load of dissolved salts withdrawn from West Pond each month was computed from the product of the monthly volume in acre-feet and the average concentration of dissolved solids for a given month. The graph of cumulative loads shown in figure 8 indicates that AMAX pumped about 12,800,000 tons of salt into their facility from January 21 to April 6, 1988. Assuming a 5 percent error in AMAX pumpage estimates, withdrawal of salt was estimated to range from 12.2 to 13.4 million tons or about 3.6 to 4.0 percent of the quantity pumped from Great Salt Lake.

\section{Outflow through Newfoundland Weir}

Outflow from West Pond is controlled by a 1,004 foot-long weir in the Newfoundland Dike. The weir consists of a series of 4-foot openings separated by segments of a solid wall. Within the openings, 4-foot long stop logs can be placed horizontally, one on top of the other, to provide for variable crest elevations.

Outflow from West Pond through the Newfoundland weir did not occur on a regular basis. Estimates provided by Bingham Engineering (Brent S. Bingham, written commun., June 17, 1990) showed that 117,000 acre-feet of brine passed through the Newfoundland weir during November 16, 1987, to April 6, 1988 (fig. 9). The amount of salt to leave West Pond via the weir during April 10, 1987, to April 6, 1988, is about $40.6 \mathrm{mill}$ ion tons or about 12 percent of the salt that was pumped from Great Salt Lake. 

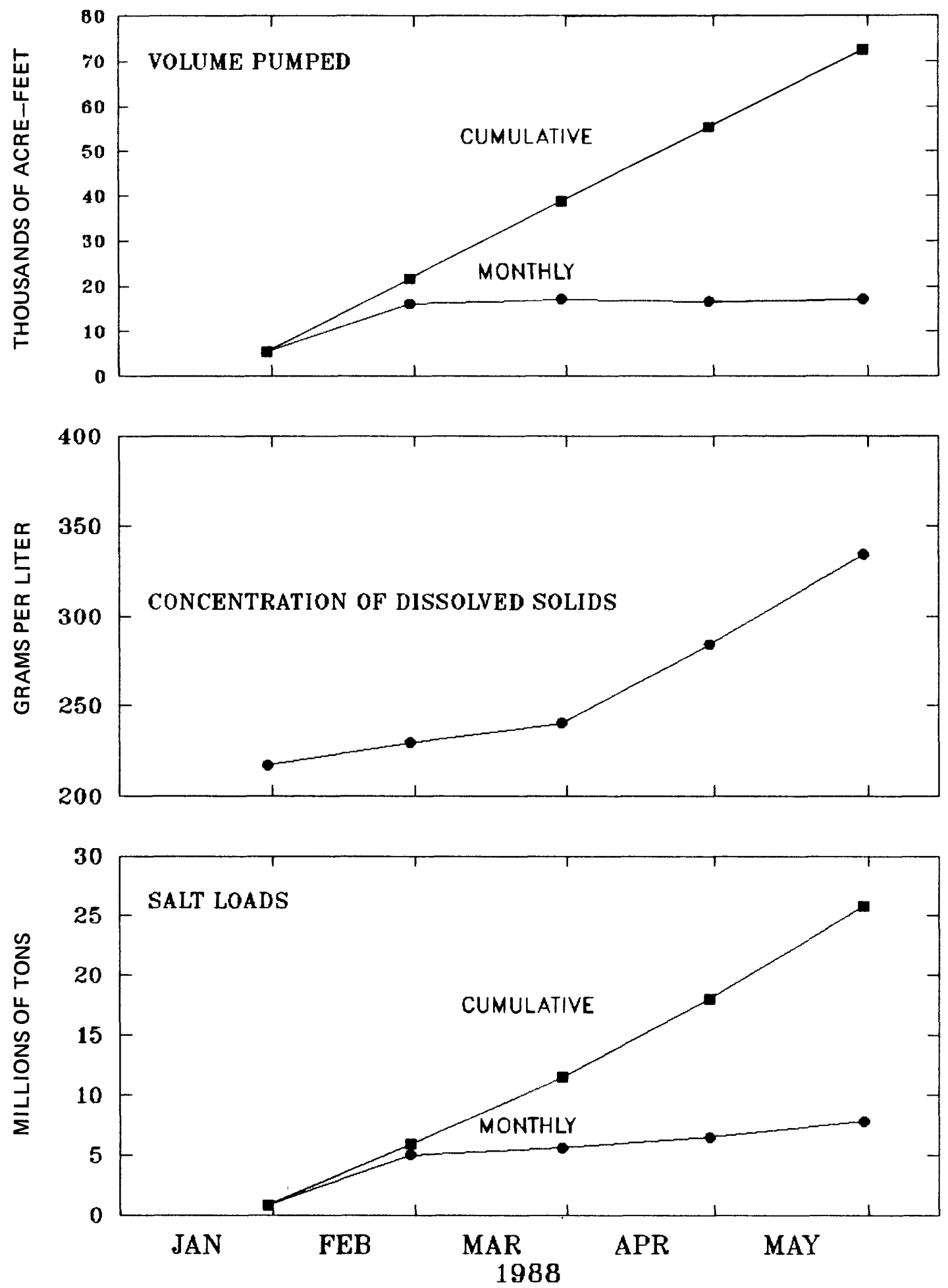

Figure 8.--Volumes, concentration of dissolved solids, and salt loads of brine pumped from West Pond into American Magnesium Corporation solar ponds, January to May 1988. 

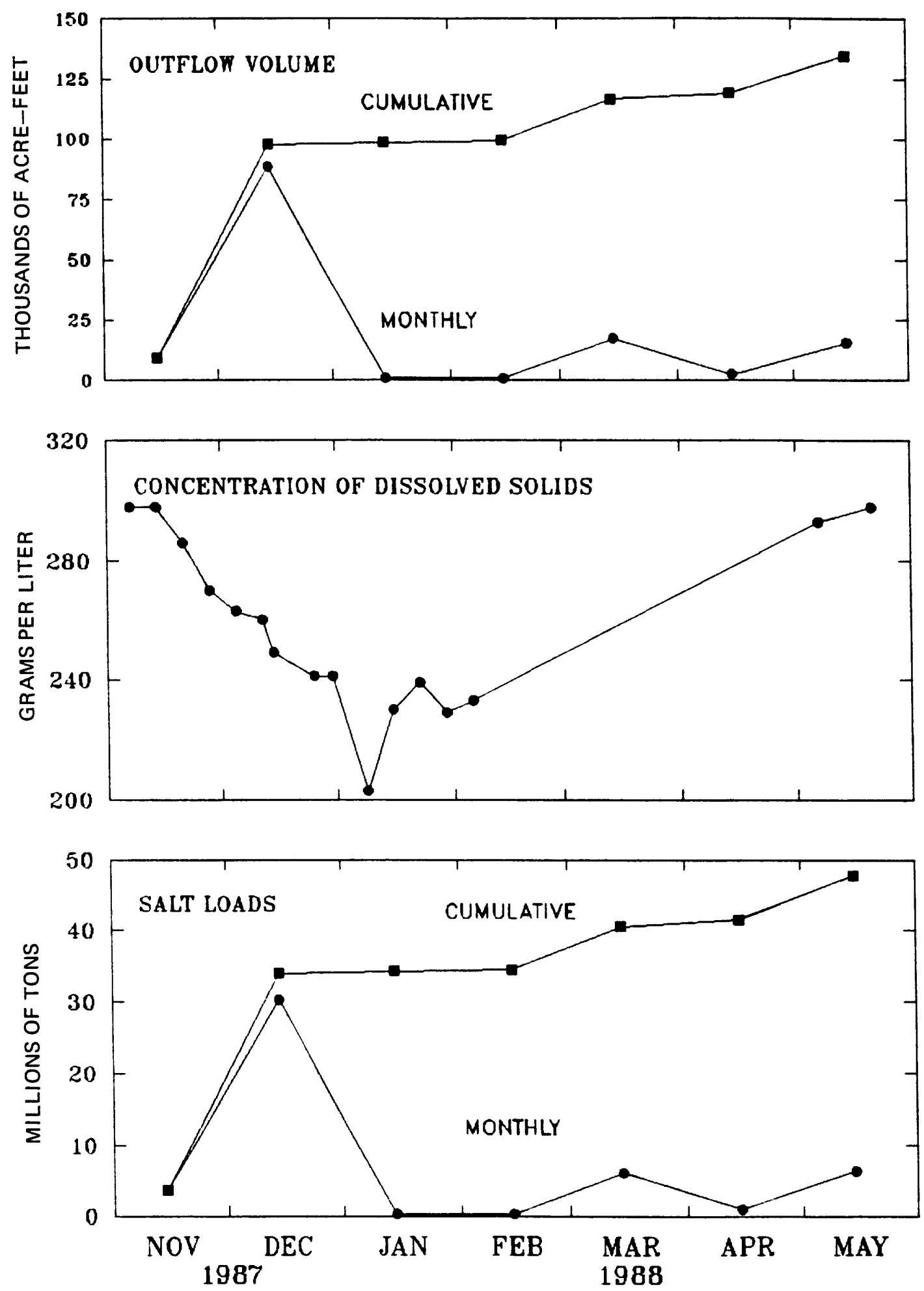

Figure 9.--Volumes, concentration of dissolved solids, and salt bads of brine for outflow from West Pond through Newfoundland weir, November 1987 to May 1988. 
Outflow through the weir was estimated using a weir rating curve. The rating curve expresses discharge as a function of the head above the weir crest. The head was determined from the difference between the pond elevation and the weir crest. A gage was installed to continuously monitor the pond elevation on December 1, 1987, but during the first six weeks of operation, the recording equipment malfunctioned; thus, for December 1, 1987, to January 13, 1988, only infrequent measurements of pond elevation are available and estimates of outflow could be quite large. The error in computing outflow during November 16, 1987, to April 6, 1988, was estimated to be plus or minus 10 percent (Brent S. Bingham, Bingham Engineering, oral comun., August 9, 1990), so the estimated tonnage of salt load that flowed through the weir ranged from 36.5 million to 44.5 million tons, which is about 11 to 13 percent of the salt that was pumped from the lake.

\section{REIURN FLOW TO GREAT SALT LAKE}

A part of the brine outflow returned to Great Salt Lake and the rest formed a small, shallow lake that occupied an area of about 60,000 acres east of the Newfoundland Mountains. This shallow lake is shown on the December 18, 1987, photo (fig. 10). The quantity of brine that returned to Great Salt Lake was estimated as the difference between the quantity of outflow through the Newfoundland weir $(117,000$ acre-feet) and the quantity stored in the shallow lake area and in the unsaturated sediments beneath the shallow lake.

Using the aerial photograph (December 18, 1987) (fig. 10) showing the shallow lake area formed by the return flow and a USGS map (scale 1:100,000), the shallow lake area was estimated to be 60,000 acres, and the average depth of the shallow lake was estimated to have ranged between 0.25 and 0.5 foot, so the volume of brine in the shallow lake ranged between 15,000 and 30,000 acrefeet. The difference between the quantity of outflow through the Newfoundland weir $(117,000$ acre-feet) and the quantity stored in the shallow lake area $(15,000$ to 30,000 acre-feet) and in the unsaturated sediments beneath the shallow lake $(3,000$ to 6,600 acre-feet $)$ is 80,400 to 99,000 acre-feet and represents the return flow to Great Salt Lake. Estimates of infiltration were made using a procedure similar to computations of subsurface storage beneath the floor of West Pond (see section "Storage in West Pond").

Assuming that the concentration of dissolved solids in the return flow to Great Salt Lake was the same as the discharge-weighted average of the outflow from the weir ( 255 grams per liter), the total salt load returned to Great Salt Lake ranged from about 28 to 34 million tons. The quantity of salt returned to Great Salt Lake is about 8 to 10 percent of the quantity pumped from the lake.

\section{SUMMARY}

During the first year of the West Desert pumping project (April 10, 1987, to April 6, 1988), a salt budget was prepared that indicates about 317 to 351 million tons of salt was pumped from Great Salt Lake into West Pond. About 28 to 34 million tons or 8 to 10 percent of salt pumped was returned to Great Salt Lake. 

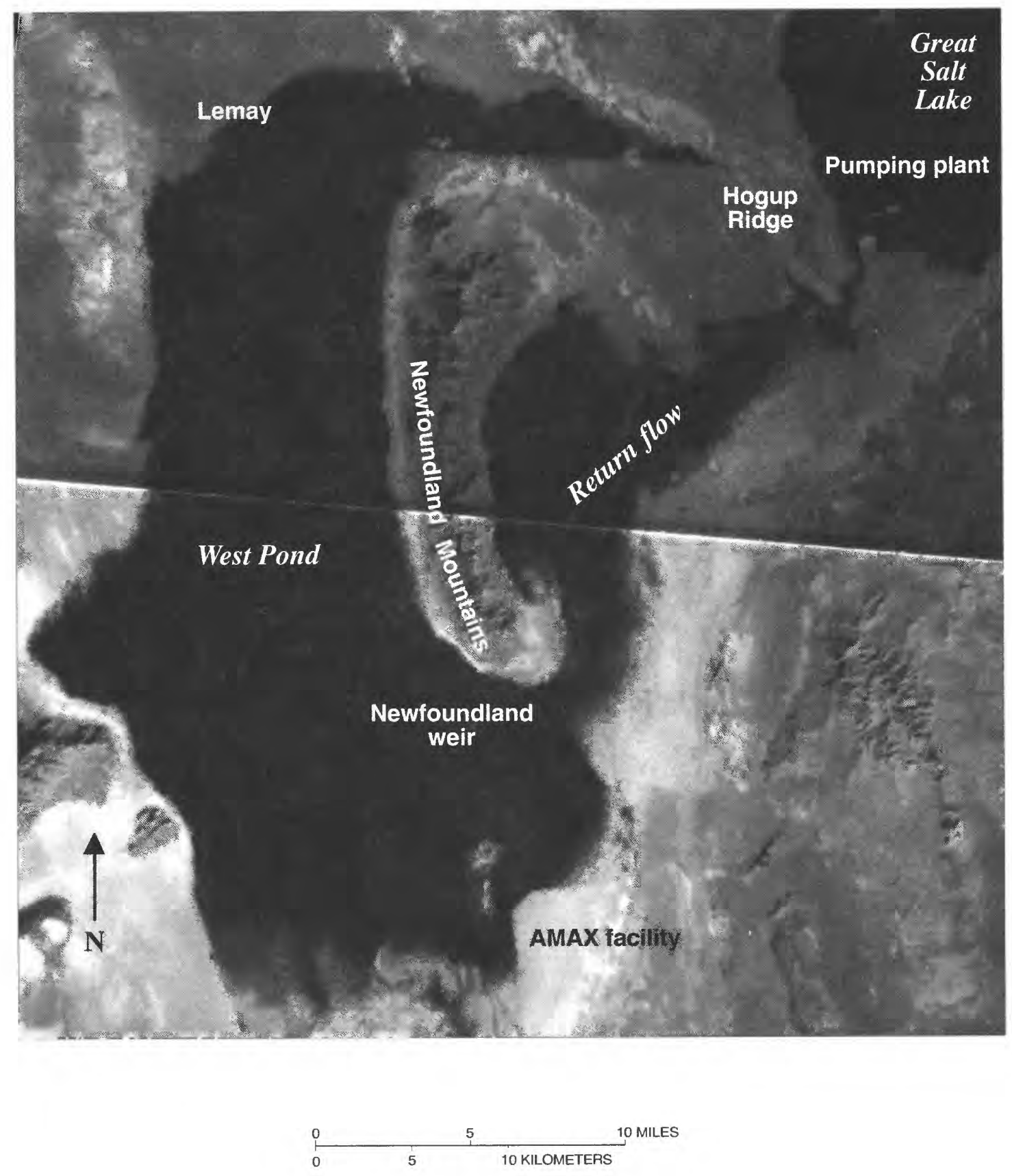

Figure 10.--View of West Pond and return flow to Great Salt Lake, December 18, 1987. (Multi-spectral photos, a Landsat photo product, purchased from EOSAT Co., Lanham, Maryland.) 
of the quantity of salt pumped into West Pond, about 64 percent was stored in West Pond. The remaining quantity, about 36 percent, comprised withdrawal by American Magnesium Corporation, subsurface infiltration into areas inundated by storage in West Pond, and discharge from West Pond through the Newfoundland weir.

About 17 percent of the salt pumped from the lake could not be accounted for by the monitoring program. Most of the inaccuracy in the budget is believed to be associated with the elevation-volume relations that affect the computed salt loads stored in West Pond. The elevation-volume curve prepared by EWP shows that at an elevation of 4,216.35 feet, the volume is about 24 percent larger than computed using elevation-volume relations developed using the U.S. Geological Survey map, scale 1:100,000. The salt loads computed using elevation-volume relations prepared by EWP increased the salt load to $240 \mathrm{million}$ tons.

\section{REFERENCES CITED}

Chapman, W.H., and Sappington, W.L., 1986, Basin contours at the northern section of Great Salt Lake Desert, Utah: U.S. Geological Survey OpenFile Report 86-009, 1:100,000-scale map.

Eckhoff, Watson, and Preator Engineering, and Dames and Moore, 1985, Appendix $A$, in Facilities and appurtenances study related to the EIS for West Desert pumping alternatives: unpublished report submitted to the Utah Division of Water Resources, March 1985, Salt Lake City, Utah.

Johnson, A.I., 1967, Specific yield - Compilation of specific yields for various materials: U.S. Geological Survey Water Supply Paper 1662-D, 74 p. 
Table 6.--Compilation of volumes and salt loads for sections of West Pond, April 4-6, 1988

[Section: See text for explanation of number system of sections]

SECTION A-N

\begin{tabular}{crrr}
$\begin{array}{c}\text { Elevation, } \\
\text { in feet above } \\
\text { sea level }\end{array}$ & $\begin{array}{c}\text { Incremental } \\
\text { volume } \\
\text { (acre-feet) }\end{array}$ & $\begin{array}{c}\text { Concentration of } \\
\text { dissolved solids } \\
\text { (grams/liter) }\end{array}$ & Tons \\
\hline 4,215 & 166.40 & 211 & 47,750 \\
4,216 & $1,820.50$ & 206 & 510,000 \\
4,217 & $8,977.30$ & 203 & $2,478,000$ \\
$4,217.5$ & $8,957.80$ & 202 & $2,461,000$ \\
TOTAL & $19,922.00$ & & $5,496,750$ \\
\hline
\end{tabular}

SECTION A-S

\begin{tabular}{crrr}
$\begin{array}{c}\text { Elevation, } \\
\text { in feet above } \\
\text { sea level }\end{array}$ & $\begin{array}{c}\text { Incremental } \\
\text { volume } \\
\text { (acre-feet) }\end{array}$ & $\begin{array}{c}\text { Concentration of } \\
\text { dissolved solids } \\
\text { (grams/liter) }\end{array}$ & \multicolumn{1}{c}{ Tons } \\
\hline 4,214 & 323.50 & 212 & 93,270 \\
4,215 & $3,125.10$ & 211 & 896,800 \\
4,216 & $6,720.60$ & 206 & $1,883,000$ \\
$4,216.35$ & $2,831.70$ & 203 & 781,800 \\
TOTAL & $-13,000.90$ & & $3,654,870$
\end{tabular}

SECTION A-B

\begin{tabular}{rrrr}
$\begin{array}{c}\text { Elevation, } \\
\text { in feet above } \\
\text { sea level }\end{array}$ & $\begin{array}{r}\text { Incremental } \\
\text { volume } \\
\text { (acre-feet) }\end{array}$ & $\begin{array}{c}\text { Concentration of } \\
\text { dissolved solids } \\
\text { (grams/liter) }\end{array}$ & Tons \\
\hline $4,211.00$ & 8.28 & 230 & 2,590 \\
$4,212.00$ & 190.83 & 226 & 58,654 \\
$4,213.00$ & $2,221.62$ & 221 & 667,730 \\
$4,214.00$ & $9,552.67$ & 215 & $2,793,201$ \\
$4,215.00$ & $17,863.62$ & 212 & $5,150,439$ \\
$4,216.00$ & $21,904.39$ & 209 & $6,226,104$ \\
$4,216.35$ & $8,201.50$ & 207 & $2,308,886$ \\
& $-59,942.91$ & & $17,207,603$
\end{tabular}


Table 6.--Compilation of volumes and salt loads for sections of West Pond, April 4-6, 1988--Continued

SECTION B-C

\begin{tabular}{crrr}
$\begin{array}{c}\text { Elevation, } \\
\text { in feet above } \\
\text { sea level }\end{array}$ & $\begin{array}{r}\text { Incremental } \\
\text { volume } \\
\text { (acre-feet) }\end{array}$ & $\begin{array}{c}\text { Concentration of } \\
\text { dissolved solids } \\
\text { (grams/liter) }\end{array}$ & Tons \\
\hline $4,210.00$ & 392.87 & 230 & 122,890 \\
$4,211.00$ & $1,646.80$ & 230 & 515,119 \\
$4,212.00$ & $3,025.03$ & 229 & 942,115 \\
$4,213.00$ & $6,172.73$ & 226 & $1,897,250$ \\
$4,214.00$ & $10,773.78$ & 223 & $3,267,472$ \\
$4,215.00$ & $13,449.76$ & 221 & $4,042,460$ \\
$4,216.00$ & $14,443.10$ & 219 & $4,301,733$ \\
$4,216.35$ & $5,220.60$ & 217 & $1,540,703$ \\
& $-5,124.67$ & & $16,629,743$
\end{tabular}

SECTION C-D

\begin{tabular}{crrr}
$\begin{array}{c}\text { Elevation, } \\
\text { in feet above } \\
\text { sea level }\end{array}$ & $\begin{array}{c}\text { Incremental } \\
\text { volume } \\
\text { (acre-feet) }\end{array}$ & $\begin{array}{c}\text { concentration of } \\
\text { dissolved solids } \\
\text { (grams/liter) }\end{array}$ & Tons \\
\hline $4,211.00$ & 753.73 & 233 & 238,842 \\
$4,212.00$ & $1,947.69$ & 233 & 617,184 \\
$4,213.00$ & $2,969.39$ & 232 & 936,902 \\
$4,214.00$ & $4,470.50$ & 230 & $1,398,372$ \\
$4,215.00$ & $6,530.67$ & 226 & $2,007,267$ \\
$4,216.00$ & $8,484.62$ & 225 & $2,596,294$ \\
$4,216.35$ & $3,304.11$ & 225 & $1,011,058$ \\
& $-28,460.71$ & & $-8,805,918$
\end{tabular}

SECTION D-E

\begin{tabular}{crrr}
$\begin{array}{c}\text { Elevation, } \\
\text { in feet above } \\
\text { sea level }\end{array}$ & $\begin{array}{r}\text { Incremental } \\
\text { volume } \\
\text { (acre-feet) }\end{array}$ & $\begin{array}{c}\text { Concentration of } \\
\text { dissolved solids } \\
\text { (grams/liter) }\end{array}$ & Tons \\
\hline $4,210.00$ & 102.79 & 235 & 32,852 \\
$4,211.00$ & 962.33 & 235 & 307,561 \\
$4,212.00$ & $2,819.45$ & 235 & 901,096 \\
$4,213.00$ & $5,634.47$ & 234 & $1,793,114$ \\
$4,214.00$ & $9,429.69$ & 233 & $2,988,080$ \\
$4,215.00$ & $14,694.81$ & 232 & $4,636,506$ \\
$4,216.00$ & $21,132.79$ & 230 & $6,610,337$ \\
$4,216.35$ & $8,649.30$ & 230 & $2,705,501$ \\
& $-2-30$ & & $-19,975,047$
\end{tabular}


Table 6.--Compilation of volumes and salt loads for sections of West Pond, April 4-6, 1988--Continued

SECTION E-F

\begin{tabular}{crrr}
$\begin{array}{c}\text { Elevation, } \\
\text { in feet above } \\
\text { sea level }\end{array}$ & $\begin{array}{c}\text { Incremental } \\
\text { volume } \\
\text { (acre-feet) }\end{array}$ & $\begin{array}{c}\text { Concentration of } \\
\text { dissolved solids } \\
\text { (grams/liter) }\end{array}$ & Tons \\
\hline $4,212.00$ & $1,163.36$ & 242 & 382,885 \\
$4,213.00$ & $5,105.19$ & 242 & $1,680,220$ \\
$4,214.00$ & $12,358.89$ & 241 & $4,050,750$ \\
$4,215.00$ & $19,433.99$ & 239 & $6,316,824$ \\
$4,216.00$ & $25,408.01$ & 238 & $8,224,065$ \\
$4,216.35$ & $10,505.11$ & 235 & $3,357,433$ \\
TOTAL & $73,974.55$ & & $-24,012,177$
\end{tabular}

SECTION F-G

\begin{tabular}{crrr}
$\begin{array}{c}\text { Elevation, } \\
\text { in feet above } \\
\text { sea level }\end{array}$ & $\begin{array}{r}\text { Incremental } \\
\text { volume } \\
\text { (acre-feet) }\end{array}$ & $\begin{array}{c}\text { Concentration of } \\
\text { dissolved solids } \\
\text { (grams/liter) }\end{array}$ & Tons \\
\hline $4,211.00$ & 490.71 & 248 & 165,507 \\
$4,212.00$ & $5,839.54$ & 248 & $1,969,560$ \\
$4,213.00$ & $15,127.97$ & 248 & $5,102,362$ \\
$4,214.00$ & $23,049.98$ & 248 & $7,774,297$ \\
$4,215.00$ & $33,265.61$ & 248 & $11,219,825$ \\
$4,216.00$ & $43,703.27$ & 248 & $14,740,239$ \\
$4,216.35$ & $16,905.42$ & 248 & $5,701,860$ \\
& $-138,382.50$ & & -
\end{tabular}

SECTION G-H

\begin{tabular}{crrr}
$\begin{array}{c}\text { Elevation, } \\
\text { in feet above } \\
\text { sea level }\end{array}$ & $\begin{array}{c}\text { Incremental } \\
\text { volume } \\
\text { (acre-feet) }\end{array}$ & $\begin{array}{c}\text { Concentration of } \\
\text { dissolved solids } \\
\text { (grams/liter) }\end{array}$ & Tons \\
\hline $4,213.00$ & 447.90 & 246 & 149,849 \\
$4,214.00$ & $5,260.88$ & 246 & $1,760,080$ \\
$4,215.00$ & $18,883.91$ & 248 & $6,369,165$ \\
$4,216.00$ & $42,169.45$ & 250 & $14,337,613$ \\
$4,216.35$ & $19,745.98$ & 250 & $6,713,633$ \\
TOTAL & $-86,508.12$ & & $-29,330,341$
\end{tabular}


Table 6.-Compilation of volumes and salt loads for sections of West Pond, April 4-6, 1988--Continued

\section{SECTION H}

\begin{tabular}{crrr}
$\begin{array}{c}\text { Elevation, } \\
\text { in feet above } \\
\text { sea level }\end{array}$ & $\begin{array}{c}\text { Incremental } \\
\text { volume } \\
\text { (acre-feet) }\end{array}$ & $\begin{array}{c}\text { concentration of } \\
\text { dissolved solids } \\
\text { (grams/liter) }\end{array}$ & Tons \\
\hline $4,214.00$ & 418.21 & 268 & 152,429 \\
$4,215.00$ & $4,392.45$ & 267 & $1,594,986$ \\
$4,216.00$ & $25,626.11$ & 265 & $9,235,650$ \\
$4,216.35$ & $17,275.07$ & 265 & $6,225,935$ \\
TOTAL & $47,711.84$ & & $-17,209,001$ \\
\hline
\end{tabular}

